\title{
The Ordovician succession adjacent to Hinlopenstretet, Ny \\ Friesland, Spitsbergen
}

\section{Kroger, Bjorn}

2017-09-05

Kroger , B , Finnegan , S , Franeck , F \& Hopkins, M J 2017 , ' The Ordovician succession adjacent to Hinlopenstretet, Ny Friesland, Spitsbergen ' , American Museum Novitates , no. 3882 , pp. 1-28 . https://doi.org/10.1206/3882.1

http://hdl.handle.net/10138/308335

https://doi.org/10.1206/3882.1

cc_by

acceptedVersion

Downloaded from Helda, University of Helsinki institutional repository.

This is an electronic reprint of the original article.

This reprint may differ from the original in pagination and typographic detail.

Please cite the original version. 


\section{The Ordovician succession adjacent to Hinlopenstretet, Ny Friesland, Spitsbergen}

Abstract: The Ordovician sections along the western shore of the Hinlopen Strait, Ny

7 Friesland, were discovered in the late 1960s and since then prompted numerous

8 paleontological publications; several of them are now classical for the paleontology of

9 Ordovician trilobites, and Ordovician paleogeography and stratigraphy. Our 2016 expedition aimed in a major recollection and reappraisal of the classical sites. Here we provide a first high-resolution lithological description of the Kirtonryggen and Valhallfonna formations (Tremadocian -Darriwilian), which together comprise a thickness of $843 \mathrm{~m}$, a revised bio-, and lithostratigraphy, and an interpretation of the depositional sequences. We find that the sedimentary succession is very similar to successions of eastern Laurentia; its Tremadocian and early Floian part is composed of predominantly peritidal dolostones and limestones characterized by ribbon carbonates, intraclastic conglomerates, microbial laminites, and stromatolites, and its late Floian to Darriwilian part is composed of fossil-rich, bioturbated, cherty mud-wackestone, skeletal grainstone and shale, with local siltstone and glauconitic horizons. The succession can be subdivided into five third-order depositional sequences, which are interpreted as representing the SAUK IIIB Supersequence known from elsewhere on the Laurentian platform. 
The Ordovician sections along the western shore of the Hinlopen Strait (Hinlopenstretet),

Ny Friesland, were discovered by accident in 1966, when an expedition team from the

Cambridge University stopped to collect water from a melt stream and collected several well preserved trilobites (Fortey and Bruton, 2013). This discovery prompted two focused collection trips during the summers of 1967 (Vallance and Fortey, 1968) and 1972 (Fortey and Bruton, 1973) that resulted in a classic series of publications focused on the trilobite successions (e.g. Fortey, 1974a,b, 1975a,b, 1980a) and accompanying fauna (e.g. brachiopods: Hansen and Holmer, 2011; conodonts: Lehnert et al., 2013; graptolites: Fortey, 1971, Cooper and Fortey, 1982; heterostracans: Bockelie and Fortey, 1976; mollusks: Evans and King, 1990; Morris and Fortey, 1976; ostracods: Williams and Siveter, 2008; radiolarians: Maletz and Bruton, 2005). Some of these publications have been influential in shaping approaches to paleogeographical reconstructions: At Hinlopen Strait the interplay between depth-related biofacies (“community types” of Fortey, 1975b), paleogeographical provinces, and sea level fluctuation became evident (e.g., Cocks and Fortey, 1982). Other publications on the Hinlopen Strait succession had a significant impact on discussions about Ordovician stratigraphy. The Valhallan Stage was based on a section of the Hinlopen Strait; it was suggested in Fortey (1980a) to represent a time interval that previously has not been recognised in many North American sections because of a widespread hiatus on the continent. The Valhallan Stage, which is equivalent to the lower Dapingian Stage in modern terms, was never formally accepted, but its recognition was a significant step toward a supraregional stratigraphic correlation of this particular time interval (see Ross et al., 1997).

Despite the scientific importance of the Hinlopen Strait sections very few subsequent expeditions have been made. It took 34 years, after which in short sequence three expeditions made stops in the area, collected Ordovician samples and remeasured the sections: In 2005 a 
group of the Polar Marine Geological Research Expedition (PMGRE) reappraised the sedimentary succession in context of a larger mapping project (Kosteva and Teben'kov, 2006); in 2007 a group from the German Bundesanstalt für Geowissenschaften und Rohstoffe (Federal Institute for Geosciences and Natural Resources) measured some sections at Hinlopen Strait and took biostratigraphic (conodont) samples in context of their project Circum-Arctic Structural Events 10 (CASE 10) (Lehnert et al., 2013); and in 2008 a Norwegian-Swedish Group lead by Nils-Martin Hanken of the University of Troms $\emptyset$ visited the area and made some focused paleontological collections, but had bad luck with weather/snow conditions and polar bears (Hansen and Holmer, 2010, 2011). Consequently, no major attempt to resample the sections at Hinlopen Strait has been made since 1972. Further, no attempt has been made by any previous expeditionary team to describe and reconstruct the paleoenvironmental succession in detail.

The goal of our 2016 expedition was to measure and describe in detail the lithology and stratigraphy of the Ordovician rocks at its two main outcrop sites Profilstranda and Olenidsletta (Fig. 1) and to collect paleontological and geochemical samples at high stratigraphic resolution. Herein, we provide the first results of this expedition, a detailed lithological description of the measured sections, a new high resolution stratigraphy, and an interpretation of the depositional sequences and its corresponding relative sea-level changes. The description will be the basis of a number of forthcoming publications with paleontological and geochemical focus.

The study area is on the northeastern edge of Ny Friesland on the island of Spitsbergen of the Svalbard archipelago, Norway, adjacent to the Hinlopen Strait (Hinlopenstretet), which divides Spitsbergen from Nordaustlandet (Fig. 1). This region comprises two exposure areas 
of lower Paleozoic rocks of the Oslobreen Group, Hinlopenstretet Supergroup: one north (Basissletta) and one south (Olenidsletta) of the Buldrebreen arm of the Valhallfonna glacier at small cliffs along the coast line and in melt stream beds. The exposed sediments are subdivided into the Tokammane, Kirtonryggen, and Valhallfonna formations of the Oslobreen Group (Harland et al., 1966; Fortey and Bruton, 1973; Harland, 1997) and range from the Early Cambrian to the Middle Ordovician. The Kirtonryggen Formation comprises the Spora, Basissletta, and Nordporten members, and the Valhallfonna Formation is subdivided into the Olenidsletta and Profilbekken members (Fortey and Bruton, 1973, see details below). The Kap Sparre Formation in Nordauslandet on the eastern side of Hinlopenstretet is correlative to the Olsobreen Group, but high-resolution comparisons of the two are hampered by a of lack of biostratigraphic data in the former (Stouge et al., 2011). The pre-Carboniferous basement of the Svalbard archipelago consists of a number of tectonostratigraphically distinct terranes that were stretched along the margin of Laurentia in pre-Caledonian times (Gee and Page, 1994; Gee and Teben'kov, 2004). The study area is part of the Nordaustlandet terranes of eastern Svalbard which in tectonic reconstructions are placed in close proximity to the Franz Joseph allochthon of North-Eastern Greenland (Smith and Rasmussen, 2008). During the mid-Paleozoic the sediments of the Hinlopenstretet Supergroup underwent minor folding with predominant NNW-SSE strike directions (Harland, 1997). The Hinlopenstretet Supergroup is generally little or not metamorphosed (Gee and Teben'kov, 2004).

In the southern outcrop area a roughly N/S directed Mesozoic dolerite intrusion limits the western expansion of the exposure of the early Paleozoic sediments. The intrusion is part of a complex of Late Jurassic - Early Cretaceous dolerites which are more widespread in the southern part of the Hinlopen Strait (Halvorsen, 1989). 
The data presented herein are the result of a joint expedition of the authors $(\mathrm{BK}, \mathrm{FF}, \mathrm{MH}$, SF), and the camp manager Hårvard Kårstad during July and August, 2016. We traveled to Ny Friesland by boat and built a campsite at Profilbekken (7950'17.9'N / 017²'’19.9'W).

The Olenidsletta area was accessible to us from Profilstranda across the Buldrebreen via rubber boat. During our expedition all visited sections were completely ice free.

We measured five sections using a Jacob's staff and clinometer, and tape measure (Fig. 1):

(1) The Spora River (SR) section and Profilstranda (PS) section form together a nearly continuous outcrop of the Basissletta and Nordporten members. The base of the SR section is within the Spora River channel just west of where the river crosses a small ridge formed by massive pinkish dolostones of the top Tokammane Formation $\left(79^{\circ} 51^{\prime} 51.0^{\prime}{ }^{\prime} \mathrm{N} /\right.$ $\left.017^{\circ} 37^{\prime} 21.2^{\prime \prime} \mathrm{E}\right)$. The SR section top is the topmost stromatolite bed at the mouth of the Spora River (7951'57.4’’N / 017³8’33.2'’E)

(2) The top of the SR section at the mouth of the Spora River is also the base of the PS section. We measured the upper part of the Basissletta Member and the complete Nordporten 113 Member southward along the Profilstranda coastline. The outcrop is nearly continuous in its 114 northern part with a minor fault and exposure gap at $59 \mathrm{~m}$ from the base of the section $115\left(79^{\circ} 51^{\prime} 41.2^{\prime \prime} \mathrm{N} / 017^{\circ} 39^{\prime} 51.5^{\prime \prime} \mathrm{E}\right)$. A number of major exposure gaps occur higher up in the 116 Basissletta Member ca. $50 \mathrm{~m}-200 \mathrm{~m}$ just north of the small headland that forms the base of

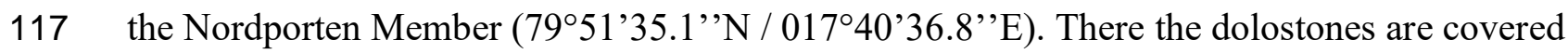
118 by several meter thick layers of modern beach gravel. From the base of the Nordporten 119 Member up to the Olenidsletta Member the outcrop is continuous. The top of the PS section 120 is the uppermost prominent hardground within the uppermost Nordporten Member at $79^{\circ} 51^{\prime} 02.9^{\prime} ’ \mathrm{~N} / 017^{\circ} 41^{\prime} 24.0^{\prime \prime} \mathrm{E}$. 
(3) The top of the PS section is the base of the overlying PO section. The PO section is just the southward continuation of the Profilstranda coastline outcrop and ends at a mouth of a small meltstream at $79^{\circ} 50^{\prime} 49^{\prime \prime} \mathrm{N} / 017^{\circ} 42^{\prime} 04^{\prime \prime} \mathrm{E}$. The base of the Olenidsletta Member of the Valhallfonna Formation occurs within the first 5 meters of the PO section.

(4) We measured a part of the Profilbekken Member along the Profilbekken river (section PR). The Profilbekken river cuts through the Profilbekken Member beds at a very low angle and the beds form a number of repeating folds and faults which makes a reliable thickness measurement very difficult for a large part of the section. However, it was possible to measure a continuous ca. $45 \mathrm{~m}$ thick $\log$ from a place ca. $100 \mathrm{~m}$ upstream from the river mouth, where massive skeletal grainstone beds form a shallow ridge. This is ridge is identical with the "basal algal conglomerate" ridge of Fortey (1980: 17); its top forms the top of the PR section at $79^{\circ} 50^{\prime} 36.1^{\prime \prime} \mathrm{N} / 017^{\circ} 43^{\prime} 04.5^{\prime \prime} \mathrm{E}$.

(5) We measured a complete section of the Profilbekken Member at the southern end of the Olenidsletta area. The top of the outcrop and the youngest beds of the Valhallfonna Fromation occur at promontory F where the beds form a shallow syncline $\left(79^{\circ} 46^{\prime} 43^{\prime \prime} \mathrm{N} /\right.$ 017 $54^{\prime} 20^{\prime}$ 'E; Fig. 1). We followed the anastomising meltstream just NW of promontory $\mathrm{F}$ in SW direction ca. $300 \mathrm{~m}$ upstream, which is stratigraphically downward. The outcrop is partly heavily weathered and in its upper part secondarily dolomitized.

TOKAMMANE FORMATION

General features: The uppermost ca. $40 \mathrm{~m}$ of the Tokammane Formation consist of a succession of three depositional units. The bases of these units are composed of buff- 
weathering, argillaceous, wavy-bedded, bioturbated, dolo-mudstone, flat-pebble and other

147 intraclastic conglomerates, and thin-bedded dolo-siltstone with symmetric fine-scaled ripples.

148 The top of each unit is formed by massive mounds of pinkish dolo-mudstone / dolo-

149 wackestone, which contain thrombolitic and fenestral textures, and local patches of

150 intraclastic conglomerates. The mounds have diameters of several tens of meters and at Spora

151 River are thickest at the top of the formation. Each depositional unit is capped by an

152 unconformity.

153 Detailed description: The measured section at Spora River (Fig. 2) starts at a ca. 0.5 m-

154 thick massive flat-pebble conglomerate, which has a fining-up tendency of intraclasts and an

155 erosive $3 \mathrm{~cm}$-thick irregular top. The overlying $5 \mathrm{~m}$ of buff-weathering, wavy-bedded dolo-

156 mudstone are topped by a ca. 2 m-thick massive, pinkish, fenestral dolo-mudstone. In the top

$1570.15 \mathrm{~m}$ of this pinkish mudstone, domal stromatolites occur that are up to $0.5 \mathrm{~m}$ in diameter.

158 The second unit begins above an erosional base with ca. $10 \mathrm{~m}$ of a monotonous, buff-

159 weathering, wavy-bedded, argillaceous dolo-mudstone. In the lowermost beds of this unit

160 parallel tunnels of unknown burrowers with diameters of less than $10 \mathrm{~mm}$ are common. At

161 the top of this dolostone, a more massive, pinkish unit above an erosional base marks the base

162 of the third unit. In the lower $0.2 \mathrm{~m}$, this unit is composed of patches of poorly rounded intraclastic conglomerates; above this is a 25 m-thick fenestral dolo-mud and dolowackestone, partly with a thrombolitic texture. Around $2 \mathrm{~m}$ into this unit (at $19 \mathrm{~m}$ in the section), this massive dolostone is interrupted by a $1 \mathrm{~m}$-thick layer of thin-bedded, platy- to wavy-bedded, dolo-siltstone that contains areas with small scale, symmetrical ripples and patches of flat-pebble conglomerates. Above this dolo-siltstone is a covered interval of about $10 \mathrm{~m}$, overlain by the top $13 \mathrm{~m}$ of the Tokammane Formation, which are formed by massive, pinkish, thrombolitic mounds (Fig. 3A). 
We measured the Spora Member at its type locality at Spora River, which we estimated to have a thickness of ca. $20 \mathrm{~m}$. The base of the member is well defined by a prominent erosional surface with a more than $1 \mathrm{~m}$-high relief, which cuts into the underlying Tokammane Formation. The lower ca. $10 \mathrm{~m}$ of the Spora Member consist of massive, darkgrey, burrow-churned, wavy-bedded, fossil-rich dolo-mudstone / dolo-wackestone. At its lower $2 \mathrm{~m}$, black flint nodules and thin flint layers are abundant. At a position of ca. $3 \mathrm{~m}$ from the base, a distinctive ca. $0.3 \mathrm{~m}$-thick intraclastic conglomerate with rounded ca. 10-30 mm large pebbles occurs. Fossil abundance peaks at ca. 5-7 m above the base of the member, and the fauna is dominated by small ophiletid gastropods (diameter ca. $20-30 \mathrm{~mm}$ ) and ellesmerocerid and endocerid cephalopods. Toward the top, the dolostone becomes more light-colored, buff-weathering, partly burrow-mottled (Fig. 3B), and rich in distinct trace fossils that form a network of tunnels with diameters of ca. $10 \mathrm{~mm}$ (Fig. 4A). The top of the Spora Member is lithologically transitional toward the lower Basissletta Member.

\section{BASISSLETTA MEMBER}

General: The Basissletta Member, exposed at Spora River and Profilstranda, is ca. $289 \mathrm{~m}$ thick. We placed the base of the member above the uppermost ca. $1 \mathrm{~m}$-thick burrow-mottled limestone ca. $20 \mathrm{~m}$ above the base of the Kirtonryggen Formation. Compared to the Spora Member, the lithology in the lower Basissletta Member is composed of purer, and more lightcolored, buff-weathering, platy- to wavy-bedded, burrow-churned to homogenous, sucrose dolo-mud to dolo-siltstone. Burrow-mottled horizons and distinctive trace fossils are nearly absent. The middle part of the member is highly condensed with abundant erosional surfaces, 
flat-pebble conglomerates, oolite beds, and horizons with massive dark flint nodules and

columnar to dome-shaped stromatolite beds. In its upper part argillaceous beds dominate and

197

198

199

200

201

202

203

204

205

206

207

208

209

210

211

212

213

214

215

216

217

218

interchange with skeletal dolo-wackestone to dolo-packstone that contain abundant

gastropods and trilobites. The boundary with the overlying Nordporten Member is

transitional.

Details: The lower ca. $58 \mathrm{~m}$ of the Basissletta Member consist of buff-weathering, mostly planar-bedded, homogenous to burrow-churned dolo-mudstone to dolo-siltstone. Within this interval two horizons occur that have a burrow-mottled texture and contain rare gastropods, cephalopods and sponge macrofossils (at ca. $15 \mathrm{~m}, 46 \mathrm{~m}$ above member base = at positions $80 \mathrm{~m}, 111 \mathrm{~m}$ in the SR section, respectively). The lowermost stromatolites occur as a compact, up to $0.2 \mathrm{~m}$-thick layer on an erosional surface at ca. $123 \mathrm{~m}$ in the section.

Columnar and dome-shaped stromatolites, ooid layers, intraclastic and flat-pebble conglomerates, cross-lamination textures, and erosional surfaces are common throughout the following $30 \mathrm{~m}$ (Figs 3C, 5). The most prominent erosional surface cuts as a more than $0.5 \mathrm{~m}$ thick intraclastic conglomerate with a relief of ca. $0.3 \mathrm{~m}$ into a wavy bedded dolostone with low domal stromatolites at ca. $71 \mathrm{~m}$ above the base of the member at $136 \mathrm{~m}$ in the SR section.

At the mouth of the Spora River, at the top of the SR section, ca. $88 \mathrm{~m}$ above the base of the Basissletta Member, the stromatolite-rich interval is succeeded by ca. $40 \mathrm{~m}$ of massive yellowish-grey weathering, fine-laminated dolo-siltstone, that is exposed along the coast of Profilstranda (Fig. 6A). This interval contains in some places hummocky cross stratification (Fig. 6D) and is partly rich in flint nodules. Flat-pebble and other intraclastic conglomerates occur at $101 \mathrm{~m}$ and $122 \mathrm{~m}$ above base of Basissletta Member (at $13 \mathrm{~m}$ and $34 \mathrm{~m}$ in PS section, respectively, Fig. 7). Toward the top of this interval dark-grey weathering, flint-rich, partly-nodular argillaceous dolostones and ribbon dolostone are more common. 

section, respectively), two horizons with low domal stromatolites, intraformational and flatpebble conglomerates, oolites, and erosional surfaces occur. Remarkable are teepee structures in a pyrite-rich dolostone (Fig. 6C), that are underlain by a flat pebble conglomerate and overlain by a dark-weathering, argillaceous, nodular, bioturbated dolostone at ca. $138 \mathrm{~m}$ above the base of the Basissletta Member (at PS section $50 \mathrm{~m}$ ). A ca. $0.5 \mathrm{~m}$-thick oolite bed above a massive intraformational conglomerate and below a bed of stromatolites at $145 \mathrm{~m}$ (at PS section $57 \mathrm{~m}$ ) serves as a good local marker horizon. disturbed along the coast along Profilstranda (Fig. 7). The exposed parts can be subdivided into three units. The lower ca. $20 \mathrm{~m}$-thick unit is predominantly a yellowish weathering, wavy-bedded, bioturbated dolo-mudstone rich in large flint nodules. The nodules are up to $0.4 \mathrm{~m}$ in diameter and $0.3 \mathrm{~m}$ in thickness. The middle ca. $30 \mathrm{~m}$-thick unit is rich in intraclastic and flat-pebble conglomerates, erosional surfaces, channels, cross bedding textures and contains predominantly light yellowish-grey, burrow-mottled, nodular dolostone and ribbon dolostone. Toward the top of this middle unit, hardgrounds locally occur on the top of intraclastic, channel rich dolostone beds. The topmost flat-pebble conglomerate of the Basissletta Member occurs at $198 \mathrm{~m}$ above the base of the member (at PS section $110 \mathrm{~m}$ ). The uppermost unit of the Basissletta Member is a ca. $90 \mathrm{~m}$ thick, partly covered alternation of beds of yellowish-grey, argillaceous, wavy-bedded to nodular, burrow-churned dolomudstone, more massive stylolithic burrow-churned dolo-wackestone, and tempestitic

240 skeletal - intraclastic dolo-packstone with common trilobite hash and gastropods. 
General: The Nordporten Member, exposed at Profilstranda (Fig. 7), is ca. $217 \mathrm{~m}$ thick.

244 We placed the base of the member at the basal bed of a succession of massive reddish-grey

245 weathering, burrow-churned dolo-mudstone/dolo-wackestone, rich in gastropods and

246 trilobites, which forms the northernmost point of a small headland at Profilstranda

$247\left(79^{\circ} 51^{\prime} 35.1^{\prime \prime} \mathrm{N} / 017^{\circ} 40^{\prime} 36.8^{\prime} \mathrm{E}\right)$. This bed forms the upper transitional part of an alternation

248 of massive dolo-wackestone / dolo-mudstone and argillaceous mudstone. The transition from

249 the Basissletta Member is gradual into a ca. 50 m-thick more massive succession of burrow-

250 mottled dolostone to ribbon-dolostone with erosional-topped / hardground-based repetitive

251 units. Above this succession another ca. $50 \mathrm{~m}$ are principally very similar but contain more

252 commonly hardgrounds, prominent grainstone- packstone lithologies, and scattered

253 intraclastic horizons. The upper ca. $120 \mathrm{~m}$ of the Nordporten Member consist predominantly

254 of monotonous massive grey to brownish burrow-churned, cherty dolo-mudstone / dolo-

255 wackestone. Toward the top, the succession gets more massive and hardground horizons are

256 more common.

257 Details: The base of the Nordporten Member is drawn at the base of a ca. 5 m-thick

258 massive dolostone within the upper part of the transitional unit of alternating massive

259 dolostone and nodular- to wavy-bedded argillaceous mudstone. At a position of ca. $11 \mathrm{~m}$ (PS

260 section $209 \mathrm{~m}$ ) below a prominent erosional surface / hard ground with an underlying $0.2 \mathrm{~m}$

261 oolite. This discontinuity surface is the lowest of six similar erosional surfaces (at $20 \mathrm{~m}, 29$

$262 \mathrm{~m}, 31 \mathrm{~m}, 34 \mathrm{~m}, 44 \mathrm{~m}$ above member base = at PS section $219 \mathrm{~m}, 227 \mathrm{~m}, 229 \mathrm{~m}, 232 \mathrm{~m}, 242$

$263 \mathrm{~m}$, respectively, Fig. 8), each of them with an erosional relief of less than $0.3 \mathrm{~m}$, that are

264 associated with horizons of intraclastic conglomerates and / or oolite beds. On the top of

265 some of these discontinuity surfaces, characteristic micro-mud mounds or micro-bioherms

266 with diameters of ca. $0.3 \mathrm{~m}$ and thicknesses of less than $0.2 \mathrm{~m}$ occur that commonly contain

267 trilobites and gastropods. The micro-bioherms are embedded in a matrix of planar-bedded, 
greenish-grey, argillaceous mudstone, and form the base of the six repetitive units. In each of the units the basal mudstone grades into wavy-bedded to nodular, greenish-grey mudstone to ribbon-dolostone, and finally into massive, burrow-churned dolo- mudstone/ dolowackestone. The more argillaceous intervals commonly contain networks of unbranched 272 burrows of the Gordia trace fossil type (Fig. 4B) and hummocky cross-stratification. At ca. $27356 \mathrm{~m}$ above the base of the Nordporten Member (PS section $254 \mathrm{~m}$ ), a ca. $0.4 \mathrm{~m}$-thick intraclastic conglomerate bed marks the base of a gradual facies transition towards more massive dolostones with common intraclast horizons, grainstone, and packstone layers. At ca. $65 \mathrm{~m}$ above the base of the member (PS section $263 \mathrm{~m}$ ), a ca. $1.5 \mathrm{~m}$-thick pair of brachiopod-

277 rich (Hesperonomia sp.) grain-packstone layers forms a marker horizon, which can be seen as 278 the climax of this intraclast-rich succession. The most pronounced erosional surface cuts with a relief of more than $1 \mathrm{~m}$ into an underlying dolo-packstone / dolo-grainstone lithology at 79 $\mathrm{m}$ above the base of the member (PS section $277 \mathrm{~m}$, Figs 7, 8B). The uppermost of these discontinuity-capped packstone/grainstone layers occurs at $116 \mathrm{~m}$ above the base of the Nordporten (PS section $314 \mathrm{~m}$ ) within a ca. 50 m-thick succession very rich in chert nodules. The top of a gradual facies change is marked by a prominent hardground at $162 \mathrm{~m}$ above the base of the Nordporten Member (PS section $360 \mathrm{~m}$ ) leading to ca. $60 \mathrm{~m}$ of very massive, grey-weathering, nodular, heavily bioturbated mudstone / wackestone lithologies with common discontinuity surfaces and hardgrounds that are most densely concentrated near the 287 top of the member. The top $3 \mathrm{~m}$ of the formation are very rich in cephalopods and gradually change toward darker, more argillaceous mudstone lithologies. 

mudstone with a transitional lithology at its lower boundary. At Profilstranda the thickness of

294

295 the Olenidsletta Member is approximately $160 \mathrm{~m}$ (Fig. 9). A precise thickness specification is impossible for the Profilstranda section because the uppermost part is locally covered and the boundary interval crops out only a few 100 meters SW in the Profilbekken River section. We placed the base of the Olenidsletta Member $3 \mathrm{~m}$ within the cephalopod-rich limestone that marks the transition interval from the Nordporten to the Olenidsletta Member $\left(79^{\circ} 51^{\prime} 02.9^{\prime}{ }^{\prime} \mathrm{N}\right.$ / $017^{\circ} 41^{\prime} 24.0^{\prime}$ 'E.). This boundary bed marks the top of the underlying massive, hardgroundrich limestone unit of the Nordporten Member and is $6 \mathrm{~m}$ below the uppermost cephalopod occurrence within the transitional interval. The top of the member is not now exposed at Profilstranda, but at the nearby Profilbekken River, where it can be traced in several places across repeating fold sections (see below). Lithologically, the Olenidsletta Member can be roughly subdivided into four transitional intervals. The lowermost 5 meters are predominantly composed of dark, massive, stylolithic, bioturbated lime-mudstone with cephalopod coquina / cephalopod packstone interlayers. The overlying ca. 87 meters are an alternation of densely laminated, dark lime-mudstone and bituminous black shale with bedding thicknesses varying between $0.05-0.3 \mathrm{~m}$, which are intermittently rich in graptolites. This shale-rich interval is overlain by a ca. $35 \mathrm{~m}$-thick interval of a more carbonaceous limestone/shale alternation with abundant hardgrounds and beds of burrowchurned to nodular limestone, rich in trilobites, cephalopods, and inarticulate brachiopods. The upper ca. $30 \mathrm{~m}$ of the member are again dominated by black shale intervals.

Details: The lower part of the Olenidsletta Member is characterized by a gradual disappearance of bioturbated limestone horizons, an increase of black shale intervals and a gradual decrease in abundance of cephalopods and trilobites. A collection made at $1.5 \mathrm{~m}$ above the base of the member included the trilobites Tropidopyge alveus and Carolinites 
genacinaca nevadensis, confirming that this part of the section is in the lowermost interval of the Olenidsletta Member (V1a of Fortey, 1980). At $11 \mathrm{~m}$, trilobites of the overlying V1b interval (Balnibarbi ceryx, Psilocara patagiatum) were found. No cephalopods were found in any beds between $5 \mathrm{~m}$ to $97 \mathrm{~m}$ above the base of the member. A peak in graptolite abundance occurs ca. 70-90 m above the base of the Olenidsletta Member. The presence of Balnibarbi pulvurea and Balnibarbi erugata at $73 \mathrm{~m}$ and B. pulvurea at $90 \mathrm{~m}$ above the base of the member indicates that this part of the section is in the V1c interval of Fortey (1980). A conspicuous flint layer that serves as a local marker horizon occurs at $87 \mathrm{~m}$ above the base of the member. A flat conspicuous hardground at $94.4 \mathrm{~m}$ above the base of the member caps a ca. $1.5 \mathrm{~m}$-thick bioturbated limestone interval with thickening up tendency. This hardground marks the onset of a succession of more than a dozen very similar repetitive units. Many of these units start with bituminous black shale rich in large inarticulate brachiopods, that grade into massive, nodular, bioturbated lime-mudstone lithologies containing abundant large trilobites and orthoconic cephalopods. At $99 \mathrm{~m}$ above the member base, the hard ground marking the top of one of the repetitive units is overlain by a thin intraclastic conglomerate. At $119 \mathrm{~m}$, and $126-129 \mathrm{~m}$, the limestone contains abundant flint nodules. The bituminous lower sections of the repetitive units are especially rich in large inarticulate brachiopods (mostly Ectenoglossa) in the interval 95-110 m, and $123 \mathrm{~m}$ above the base of the member. This interval (V2a of Fortey, 1980) is also characterized by the large asaphid trilobite Gog catillus, the lowest occurrence of which was found at $103 \mathrm{~m}$ above the base of the member.

337 The top layers of the repetitive units at $119 \mathrm{~m}, 121 \mathrm{~m}$, and $128 \mathrm{~m}$ are exceptionally rich in cephalopods and trilobites and contain horizons with trilobite hash / cephalopod shell packstone. The orthoconic cephalopod shells are current aligned (Fig. 10A). We place the boundary between V2a and V2b of Fortey (1980) around $123 \mathrm{~m}$ above the base of the member (Fig. 9) based on the occurrence of late-form Bienvillia stikta, late-form 

the occurrence of Ampyx porcus and Lyrapyge ebriosus (both V2a) at $120.3 \mathrm{~m}$ above the base

344 of the member. The uppermost shale-rich part of the member begins above the hard ground at

345 the top of one of the repetitive units at $128 \mathrm{~m}$. The boundary between V2 and V3 is

346 transitional (Fortey 1980), but we place it no higher than $129 \mathrm{~m}$ above the base of the

347 member. In this part of the member, the bituminous black shale/limestone is especially rich in

348 large olenid trilobites. The upper part of the member consists of repetitive units with

349 thickness of up to $3 \mathrm{~m}$, each topped by a massive decimeter-thick limestone bed, which is

350 partly bioturbated and capped by a flat hardground. Small orthoconic cephalopods (less than

$3513 \mathrm{~mm}$ in diameter), trilobite fragments, and 3D preserved graptolites are common within the 352 top limestone layers of each of the units (Fig. 10C).

353 Although not exposed along Profilstranda, the base of the Profilbekken Member is marked 354 by an inarticulate brachiopod-rich phosphatic, skeletal packstone which represents a thin 355 horizon covering the topmost of these repetitive units. This boundary layer is exposed in 356 Profilbekken and near promontory F in the Olenidsletta area south of Buldrebreen (Fig. 1).

General: The thickness and the lithology of the Profilbekken Member varies across the outcrop area. The complete section of the Profilbekken Member exposed along the Fpromontory melt stream (section FP, Fig. 11) is ca.157 m thick. The member is also well exposed at Profilbekken River, but difficult to measure, because of faulting and folding of the beds. A part of the middle Profilbekken Member could be measured at Profilbekken River, but the correlation is problematic because of the lack of common distinct marker beds (Fig. 
bedded, slightly silicified, yellowish-grey, banded lime-mudstone (Fig. 13A) and wavybedded, bioturbated to nodular grey lime-mudstone, with a few prominent hardground horizons and more argillaceous greenish-grey intervals. In contrast, the section at Profilbekken River is divided into distinct silty-glauconitic beds and horizons dominated by intraclastic-skeletal grainstone and packstone lithologies. The upper boundary of the member is only exposed in the southern outcrop area and at section FP it is drawn at the base of the gray-green siltstone-shale unit that caps the massive limestone of the top Profilbekken Member. The upper ca. $10 \mathrm{~m}$ of the Profilbekken Member are composed of a massive, light grey weathering, bioturbated lime-mudstone / lime-wackestone with abundant hardgrounds and omission surfaces. The top of the limestone succession is formed by a prominent hardground and / or erosional surface with a ca. $0.1 \mathrm{~m}$ relief. A greenish bed of siltstone marl, rich in orchid brachiopods and pelmatozoan debris overlies this top hardground with an exposed thickness of 4 meters and forms the youngest of the beds of the Valhallfonna Formation.

Details: The base of the member is a thin (few centimeters) skeletal packstone layer, rich in inarticulate brachiopod (obolids) shell hash and trilobite cuticle fragments (Fortey and Bruton, 1973). The horizon has been found at section FP and in several places along the Profilbekken River, where it was impossible to reconstruct a coherent profile. At Profilbekken River it is evident that similar more or less phosphate-rich, thin, skeletal packstone beds exist in the top few meters of the Olenidsletta Member. These beds contain trilobite hash, brachiopod shell hash and small orthoconic cephalopods in a varying amount and are representative of the termination of individual meter scale repetitive units with thickening-up limestones at the top of the Olenidsletta Member (Fig. 10C). At section FP (Figure section FP, Fig. 11), no such phosphate rich horizon exists above the base of the Profilbekken Member but the dark, partly bituminous argillaceous-silty, laminated lime- 
mudstone, characteristic of the upper Olenidsletta Member continues for ca. $3 \mathrm{~m}$ until it grades into a $21 \mathrm{~m}$-thick succession of well-bedded, grey lime-mudstone which is partly silicified and during weathering forms characteristic yellowish-grey bands. Hardgrounds and discontinuity surfaces occur in some places in this banded limestone. A prominent hardground $11 \mathrm{~m}$ above the base of the member contains abundant large orthoconic endocerid cephalopods and trilobite hash. The particular limestone below the hardground is well bioturbated and irregularly bedded and directly above the hardground a thin intraclastic conglomerate occurs. A similar prominent hardground horizon occurs at $33 \mathrm{~m}$ above the member base. The monotonous alternation of banded silicified limestone and wavy bedded bioturbated limestone at section FP is only interrupted by two more-argillaceous, greenish weathering, partly flint, nodule-rich beds with transitional boundaries at $52-53 \mathrm{~m}$ and at 78$79 \mathrm{~m}$ from the base. It is questionable if and how these two argillaceous limestone beds relate to the distinct glauconite intervals that occur at Profilbekken River.

At Profilbekken River the lithology is much more variable in the middle part of the member with two prominent glauconite intervals that serve as local marker horizons (Fig. 12). The upper glauconite interval consists of three distinct up to $1.5 \mathrm{~m}$-thick glauconitesiltstone beds at $24 \mathrm{~m}, 29 \mathrm{~m}$, and $31 \mathrm{~m}$ (Fig.13B). Each of the glauconite beds caps a prominent bored hardground on top of the respective underlying bioturbated massive limestone. The lower glauconite interval at $4 \mathrm{~m}$ is comprised of a succession of 4-5

410 glauconite silt beds, each with a thickness of ca. $0.1 \mathrm{~m}$. The hardgrounds of the lower 411 glauconite interval differ from those in the upper interval in being strongly iron stained (Fig. 13B). Generally the lower glauconite interval appears to be very rich in dispersed pyrite. The

413 lower glauconite interval also differs from the upper interval in containing abundant large 414 orthoconic endocerid cephalopods, trilobites, gastropods (Fig. 10D). Large monaxon sponge 415 spicules and orchid brachiopods are common in the limestone beds between the two 
glauconite intervals. Crinoid ossicles are abundant throughout the measured Profilbekken section, but clearly increase in abundance toward the top, where several up to $2 \mathrm{~m}$-thick algal-pelmatozoan grainstone beds form the top of individual hardground-capped repetitive units.

\section{STRATIGRAPHICAL SUBDIVISION AND CORRELATION}

\section{PROBLEMS IN LITHOSTRATIGRAPHIC SUBDIVISION}

The lithostratigraphic subdivision of the sections described herein is based on units established by Gobbet and Wilson (1960), Harland et al. (1966), and Vallance and Fortey (1968). The formations and members are adopted without changes from Fortey and Bruton (1973). This is common practice in all publications about the Hinlopen Strait sections since the 1970s. Nonetheless, the thickness estimates given in the some of these publications vary dramatically. The most extreme differences exist between measurements of Kosteva and Teben'kov (2006) and Lehnert et al. (2013) with total thicknesses of the Kirtonryggen and Valhallfonna formations of $722 \mathrm{~m}$ and $1055 \mathrm{~m}$, respectively. Our own measurement with 843 $\mathrm{m}$ is nearly $100 \mathrm{~m}$ more than the thickness given in Fortey and Bruton (1973).

The reason for these differences must not be sought for in dissenting practices of placing boundaries of the two formations because these two boundaries are unmistakably defined by Fortey and Bruton (1973). Instead we assume that most of the discrepancies result from differences in the combination of sections from either the northern Profilbekken or the southern Olenidsletta outcrop area and/or from differences in ice conditions. During the 1971 expedition David Bruton recorded much ice in the sections and ice was also present in the sections during the 1967 expedition (David Bruton, pers. comm). This is in contrast to our 2016 expedition with complete ice and snow free conditions. Our combined section of the Profilbekken and Olenidsletta area is based on the combination of one more or less 
continuous outcrop in the northern area which starts at the Spora River in the north and

442 continues south along the shore of the Profilbekken and a second one along the F-promontory

443 melt stream in the southernmost part of the outcrop area. We did not find any major fault

444 related repetition or gap in these outcrops. But an additional short section of the Profilbekken

445 Member along the Profilbekken River illustrates the existence of significant lateral facies

446 changes between the northern and the southern outcrop area in the Profilbekken Member with

447 greatly reduced thickness in the northern outcrop area (Fig. 14). The opposite trend seems to

448 exist within the Olenidsletta Member: we measured a thickness of ca. $160 \mathrm{~m}$ in the northern

449 area whereas Fortey and Bruton (1973) report a total thickness of $145 \mathrm{~m}$ based on

450 measurements in the type area in the southern outcrop. We also found slightly different

451 thicknesses than Fortey and Bruton (1973). Our data of the Olenidsletta Member are in

452 general agreement with the biostratigraphy summarized in a pull out chart at the end of the

453 Fortey (1980) volume with all trilobite species listed. The Olenidsletta Member trilobite

454 range zones V1, and V2 are reported to have a thickness of $77 \mathrm{~m}, 29 \mathrm{~m}$, respectively in

455 Fortey (1980), measured at the Olenidsletta type section. These correspond to our thicknesses

456 of 95 m, $34 \mathrm{~m}$ measured at Profilstranda (Fig. 9).

457 It continues to be impossible to create a combined section exclusively from either the

458 northern or southern outcrop area. Hence, any combined section of the Hinlopen Strait

459 Ordovician reflects an individual synthesis across a relatively large area with significant

460 facies and thickness changes.

Additionally it can be expected that discrepancies in the individual attempts to correlate

462 between the sections led to differences in the composite log; e.g., the largest difference

463 between our measurement and that of Fortey and Bruton (1973) is within the Basissletta

464 Member. We measured a total thickness of $289 \mathrm{~m}$ for the Basissletta Member whilst Fortey

465 and Bruton (1973) measured $250 \mathrm{~m}$ at the same section. This difference is best explained by 
improved outcrop conditions since the 1970s due to less ice and snow coverage. In our section the Basissletta Member contains two intervals with stromatolites; one crops out at ca. 60-90 m above the base of the member within the Spora River and another at ca. 140-150 m above the base along the Profilbekken shoreline. The Fortey and Bruton (1973) section contains only our lower stromatolite interval. But the Profilbekken shoreline, which was easily accessible to us, was difficult to access 44 years ago (Fortey and Bruton, 1973: 2232). We did not find any signs of a major tectonic repetition of the section and are confident that the Basissletta Member contains two stromatolite-rich intervals. In our opinion the missing ca. $40 \mathrm{~m}$ of section between two measurements are a result of a missing middle part of the Basissletta Member in the Fortey and Bruton (1973) section.

A third source of discrepancies is the sometimes ambiguous placing of the member boundaries in section intervals with gradual lithology changes. The original description in Fortey and Bruton (1973) is explicit, but did not prevent quite permissive reinterpretation by some authors. The base of the Nordporten Member, e.g., is defined as "a 10 m-thick, massive, fossiliferous gray limestone forming a small headland $2 \mathrm{~km}$ to the north of the Profilbekken" (Fortey and Bruton, 1973: 2232). But it appears that Lehnert et al. (2013) placed their Nordporten Member base at a position ca. $80 \mathrm{~m}$ down in the section at a place some hundred meters toward the north of this small headland.

It is important to have these discrepancies in mind when comparing individual fossil occurrences or lithologies from the different published composite sections. These discrepancies and differing practices in logging also set important constraints for high resolution biostratigraphic and chronostratigraphic correlations. 
The biostratigraphy of the Kirtonryggen and Valhallfonna formations is primarily based on trilobites, and was first established in great detail within the Valhallfonna Formation with nine successive trilobite faunal (or assemblage) zones (Fortey, 1980). The list of trilobite faunal zones was completed for the Kirtonryggen Formation by Fortey and Bruton (2013). The conodont stratigraphy is based on Fortey and Barnes (1977), Lehnert et al. (2013), and few samples discussed in Fortey and Bruton (2013). A graptolite based stratigraphy was 496 published only for the Olenidsletta Member (Archer and Fortey, 1974; Cooper and Fortey, 1982).

Conflicting biostratigraphic data occur partly within the Kirtonryggen Formation. The Spora Member contains trilobites which have been correlated with the Laurentian LeiostegiumTesselecauda trilobite zones of Ross et al. (1997), Stairsian Regional Stage, by Fortey and Bruton (2013). In contrast, the only productive conodont sample from the Spora Member, comes from the very top of the member and contains a fauna of the Laurentian Rossodus manitouensis conodont zone, Skullrockian-Stairsian regional stages (Lehnert et al., 2013).

504 Currently no additional fossil data are available to further constrain the age of the Spora 505 Member.

The biostratigraphy of the Basissletta Member is problematic, because the fossils are rare 507 and endemic. Trilobites collected at the base of the lower stromatolite interval (ca. $60 \mathrm{~m}$ above the base of the Basissletta Member) and in fossil-poor dolo-mudstones ca. $104 \mathrm{~m}$ 509 above the base of the Basissletta Member are interpreted to represent an interval that is not 510 deposited elsewhere on Laurentia (Fortey and Bruton, 2013). Conodonts recovered from the 511 top of the lowermost stromatolite interval $\pm 90 \mathrm{~m}$ above the base of the member contain the 512 index taxon of the Macerodus dianae conodont zone (sample BS122 of Lehnert et al., 2013). 513 A sample from the topmost Basissletta Member contains conodonts indicative of the 514 Laurentian Oepikodus communis conodont zone (Fortey and Bruton, 2013: 9-10) and 
515 trilobites in the uppermost Basissletta-lowermost Nordporten Member can be correlated with 516 the Laurentian Benthamaspis rochmotis-Petigurus cullisoni trilobite zones interval (Fortey

517 and Bruton, 2013: 14), which in turn correlates with the lower part of the Oepikodus

518 communis conodont zone. Hence, the base of the Floian Stage can be expected within the

519 upper part of, but not at the top of, the Basissletta Member.

520 The biostratigraphy of the Nordporten to lower Profilbekken members is well resolved

521

522

523

524

525

526

527

528

529

530

531

532

533

534 535

536

537

538 and the trilobite, graptolite, and conodont data are consistent. But few data are available for the Profilbekken Member. Conodonts collected from a bed in between the two main glauconite horizons at Profilbekken River indicate a stratigraphic position within the

Paroistodus originalis - Baltoniodus norrlandicus conodont zones and within the Isograptus victoriae maximodivergens - Levisograptus graptolite zones (sample BS66 of Lehnert et al., 2013) near the Dapingian - Darriwilian stage boundary. The trilobites above a level of ca. 30 $m$ in the Profilbekken Member section of Fortey and Bruton (1973) are considered to be correlative with the Whiterockian Orthidiella trilobite zone of Laurentia, but this level could not be located with confidence in our sections, and it is questionable if it is below BS66 of Lehnert et al. (2013) at the position near the lowermost glauconitic horizons.

This short overview reveals that large intervals of the Kirtonryggen and Valhallfonna formations need a better biostratigraphic resolution, but with the current data the possibilities are limited. A higher biostratigraphic resolution of the sections is also crucial for a reliable interregional correlation of the depositional sequences of the Hinlopen sections.

\section{SEQUENCE STRATIGRAPHY}

The succession of the Kirtonryggen and Valhallfonna formations is in several aspects very similar to time equivalent carbonate successions of the eastern paleomargin of Laurentia, and 
can be directly compared with the Early to early Middle Ordovician carbonates of the central

540 Appalachian Basin (compare Pope and Read, 1997; Brezinski et al., 2012) and of western

541 Newfoundland (compare Pratt and James, 1986, Knight and James, 1987; Knight et al.,

542 2007). The Kirtonryggen Formation is mainly composed of fossiliferous bioturbated mud-

543 wackestone, ribbon carbonate, intraclastic (predominately flat-pebble) conglomerate,

544 grainstone and oolite, and microbial laminite. These lithologies form units of shallowing-up

545 meter- to tens-of-meter-scale parasequences.

546 In comparison, the Lower Ordovician part of the Knox Group of the central Appalachians

547 consists of a number of third-order depositional sequences that are composed of dozens of

548 meter-scale shallowing upward peritidal parasequences with common flat-pebble

549 conglomerates and oolites at their base, low domal stromatolites in their middle parts, and 550 cryptal laminites at their top. The deeper depositional settings of this part of the Knox Group

551

552

553

554

555

556

557

558

559

560

561

562

563 consists of subtidal ribbon carbonates and more massive microbial bioherms (Pope and Read, 1998). On western Newfoundland the Lower Ordovician part of the St. George Group consists of peritidal carbonates that range from supratidal cryptalgal laminates, intertidal ribbon carbonates, and stromatolites to deeper subtidal thrombolite mounds and fossiliferous wackestone (Pratt and James, 1986).

This general similarity of the carbonate successions of eastern Laurentia, including those of Spitsbergen, is even more compelling when considering their general change in sedimentation style toward the Middle and Late Ordovician. The uppermost parts of the Nordporten Member and Olenidsletta Member record a substantial rise in sea level accompanied by a change of the lithology toward dark, bituminous mud-wackestone and shale lithologies. At the top of the Olenidsletta Member and within the Profilbekken Member the sea level returned to levels comparable to that of the Nordporten Member, but the lithology does not return to a Kirtonryggen facies. Instead the Profilbekken lithologies are 
dominated by massive mud-wackestone, partly rich in dispersed silica and/or chert, skeletal

565

566

567

568

569

570

571

572

573

574

575

576

577

578

579

580

581

582

583

584

585

586

587

588

pack-grainstone (rich in pelmatozoan ossicles and algal fragments), shale-siltstone, and glauconite-rich beds. In the Profilbekken Member, the limestone forms parasequences with thicknesses of a few to tens of meters with shale-siltstone beds at their bases, mudwackestone beds as main parts, and partly skeletal grain-packstone layers at their top. The parasequences are capped by prominent hardgrounds, which are heavily bored on, and may be phosphate or iron encrusted. With the exception of the glauconite beds, this facies is very similar to the High Bridge and St. Paul Group of Kentucky and Virginia (Pope and Read, 1998). This Early to Late Ordovician facies change across eastern Laurentia has been interpreted as reflecting major climatic change during the Ordovician (Pope and Read, 1998; Pope and Steffen, 2003).

Despite this general similarity in facies pattern it is difficult to correlate individual depositional sequences of the Kirtonryggen and Valhallfonna formations with that other regions of Laurentia. Five third-order depositional sequences can be distinguished within the Kirtonryggen and Valhallfonna formations (Fig. 14). Generally, the five sequences can be interpreted as part of the Laurentian SAUK IIIB Supersequence (Morgan, 2012), which is sandwiched above the prominent basal Tremadocian Stonehenge transgression (Taylor et al. 1992) and below the Darriwilian base of the Tippecanoe Supersequence. The exact stratigraphic range of the hiatus at the base of the Kirtonryggen Formation is not known, and the onset of sedimentation of the Spora Member was either during the latest Skullrockian or during the earliest Stairsian regional stages (see above). But it is clear that the fossil-rich bioturbated dolostone of the Spora Member represents a deep setting that is not represented again until the upper part of the Basissletta Member. The interval between the Spora Member and the upper Basissletta Member contains two major shallowing events; both are Stairsian in age. Therefore, the Spora Member most likely represents the late part of the Stonehenge 
transgression, and the two successive lowstand intervals within the Basissletta Member can be interpreted as equivalents of the widespread Laurentian early Stairsian unconformity (e.g.: top Stonehenge Formation, central Appalachians; base Boat Harbor Formation, western Newfoundland; base Rochdale Formation, New York; Tule Valley lowstand, Utah; see Morgan, 2012), and late Stairsian unconformity (e.g.: Rochdale/Fort Cassin formations unconformity, New York; Boat Harbor unconformity, western Newfoundland; see Morgan, 2012), respectively. Consequently, our sequence I would be roughly equivalent with the upper part of the Lower Boat Harbour Formation in western Newfoundland, and our sequence II would be partly equivalent with the middle Boat Harbor Formation in western Newfoundland, and the Rochdale Formation in New York (Fig. 15). This correlation is consistent with the biostratigraphic data of the Basissletta Formation (Fortey and Bruton, 2013; Lehnert et al., 2013). A detailed correlation of the overlying sequence III is not possible with the available data, but the massive deepening at the topmost Nordporten Member / basal Olenidsletta Member can be confined with some confidence to a prominent early Floian Laurentian transgression around the O. communis / O. evae conodont zone boundary (e.g. Laignet Point Member, western Newfoundland; Fort Cassin Formation, New York; evae-transgression, northeast Greenland; see Morgan, 2012). The massive sea level drop at the lower Profilbekken Member is in accordance with the "basal widespread Whiterockian regression" and a succession of unconformities at the Floian/Dapingian boundary ultimately mark the top of the Laurentian SAUK supersequence (Morgan, 2012).

CONCLUSIONS

The Kirtonryggen and Valhallfonna formations comprise 843 m of mostly carbonaceous Early to early Middle Ordovician sediments. The sedimentary succession is in several aspects very similar to other successions of eastern Laurentia; its Tremadocian and early Floian part 
is composed of predominantly peritidal dolostones and limestones characterized by ribbon

615

616

617

618

619

620

621

622

623

624

625

626

627

628

629

630

631

632

633

634

635

636

637

carbonates, intraclastic conglomerates, microbial laminites, and stromatolites, and its late

Floian to Darriwilian part is composed of fossil-rich, bioturbated, cherty mud-wackestone,

skeletal grainstone and shale, with local siltstone and glauconitic horizons. The succession would be consistent with a general trend of Early to Middle Ordovician climate cooling.

Lateral facies differentiation complicates the local correlation of the upper Valhallfonna Formation, especially in the absence of a high-resolution biostratigraphy on this part of the succession. The biostratigraphic resolution of the Kirtonryggen and Valhallfonna formations greatly varies, depending on the position within the succession. The more restricted, shallow peritidal carbonates of the Basissletta Member contain a sparse and endemic assemblage, which cannot be directly correlated with other Laurentian areas. A comparatively highresolved biostratigraphy is possible within the graptolite rich shales and mud-limestones of the Olenidsletta Member.

Within the Kirtonryggen and Valhallfonna formations, five third-order depositional sequences can be subdivided, and which are interpreted as representing the SAUK IIIB Supersequence known from elsewhere on the Laurentian platform. A detailed correlation of the individual third-order sequences is currently difficult because of limited biostratigraphic control, but the available data suggest that especially the Stairsian and Middle Ordovician lowstand intervals are much more complete than in other Laurentian sections.

(1)

ACKNOWLEDGEMENTS

We are grateful for the general support during preparation and realization of the project by David Bruton (NHM Oslo, Norway), Ebony (Longyearbyen, Svalbard, Norway), Ethan (Profilbekken, Svalbard, Norway), Richard Fortey (NHM London), Nils Martin Hanken 
638 (Tromsø / Oslo, Norway), Håvard Hansen (Norsk Polarinstitut, Svalbard, Norway), Stig

639 Hennigsen and family (Longyearbyen, Svalbard, Norway), Jim Johansen (Norsk Polarinstitut,

640 Svalbard, Norway), Hårvard Kårstad (Ørsta, Norway), Henriika Kivilä (Helsinki, Finland),

641 Rupert Krapp (Norsk Polarinstitut, Svalbard, Norway), Lee Hsiang Liow (NHM Oslo,

642 Norway), Ivar Midtkandal (Oslo, Norway), Hans Arne Nakrem (NHM Oslo, Norway), Svend

643 Stouge (Københavns Universitet, Denmark), Mariah Slovacek (AMNH, USA), and thank

644 also the Sysselmannen på Svalbard for Permissions of Fieldwork. Fieldwork was conducted

645 under permit 2016/00110-2. The project was financially supported by the Niarchos

646 Foundation (MJH), the National Geographic Society (FF), and the Societas Scientarium

647 Fennica (BK). This work is part of Research in Svalbard (RIS) ID 10467.

648

649

650

651

652

653

654

655

656

657

658

659

660

661

\section{REFERENCES}

Archer, J.B., and R.A. Fortey. 1974. Ordovician graptolites from the Valhallfonna Formation, northern Spitsbergen. Special Papers in Palaeontology 13: 87-98.

Bergström, S.M., X. Chen, J.C. Gutiérrez-Marco, and A. Dronov. 2009. The new chronostratigraphic classification of the Ordovician System and its relation to major regional series and stages and to $213 \mathrm{C}$ chemostratigraphy. Lethaia 42: 97-107.

Bockelie, T., and R.A. Fortey. 1976. An early Ordovician vertebrate. Nature 260: 36-38.

Boyce, W.D., L.M.E. Mccobb, and I. Knight. 2011. Stratigraphic studies of the Watts Bight Formation (St. George Group), Port au Port Peninsula, western Newfoundland. Current Research. Government of Newfoundland and Labrador, Department of Natural Resources, Mines Branch, Report, 11-11.

Brezinski, D.K., J.F. Taylor, and J.E. Repetski. 2012. Sequential development of platform to off-platform facies of the great American carbonate bank in the central Appalachians. In 

Petroleum Geologists.

666

667

668

669

670

671

672

673

674

675

676

677

678

679

680

681

682

683

684

Cocks, L.R.M., and R.A. Fortey. 1982. Faunal evidence for oceanic separations in the Palaeozoic of Britain. Journal of the Geological Society 139: 465-478.

Cooper, R.A., and R.A. Fortey. 1982. The Ordovician graptolites of Spitsbergen. Bulletin of the British Museum (Natural History), Geology 36: 157-302.

Cooper, R.A., P.M. Sadler, O. Hammer, and F.M. Gradstein. 2012. Chapter 20 - The Ordovician Period. In Gradstein, F.M., J.G.O.D. Schmitz, and G.M. Ogg, (editors), The Geologic Time Scale 2012: 489-523. Boston: Elsevier.

Evans, D.H., and A.H. King. 1990. The affinities of early oncocerid nautiloids from the Lower Ordovician of Spitsbergen and Sweden. Palaeontology 33: 623-630.

Fortey, R.A. 1974. The Ordovician Trilobites of Spitsbergen: 1. Olenidae. Skrifter Norsk Polarinstitutt 160: 1-81.

Fortey, R.A. 1975a. Early Ordovician trilobite communities. Fossil and Strata 4: 331-352.

Fortey, R.A. 1975b. The Ordovician Trilobites of Spitsbergen: 2. Asaphidae, Nileidae, Raphiophoridae and Telephinidae of the Valhallfonna Formation. Skrifter Norsk Polarinstitutt 162: 1-125.

Fortey, R.A., and D.L. Bruton. 2013. Lower Ordovician trilobites of the Kirtonryggen Formation, Spitsbergen. Fossils and Strata 59: 1-116.

Fortey, R.A. 1971. Tristichograptus, a triserial graptolite from the Lower Ordovician of Spitsbergen. Palaeontology 14: 188-199. 
685

686

687

688

689

690

691

692

693

694

695

696

697

698

699

700

701

702

703

704

705

Fortey, R.A. 1980. The Ordovician Trilobites of Spitsbergen: 3. Remaining trilobites of the Valhalla Formation. Skrifter Norsk Polarinstitutt 171: 1-113.

Fortey, R.A., and D.L. Bruton. 1973. Cambrian-Ordovician rocks adjacent to Hinlopenstretet, North Ny Friesland, Spitsbergen. Bulletin of the Geological Society of America 84: $2227-2242$

Fortey, R.A. 1974. A new pelagic trilobite from the Ordovician of Spitsbergen, Ireland and Utah. Palaeontology 17: 111-124.

Gee, D.G., and L.M. Page. 1994. Caledonian terrane assembly on Svalbard: new evidence from 40Ar/39Ar dating in Ny Friesland. American Journal of Science 294: 1166-1186.

Gee, D.G., and A.M. Teben'kov. 2004. Svalbard: a fragment of the Laurentian margin. Geological Society, London, Memoirs 30: 191-206.

Gobbett, D.J., and C.B. Wilson. 1960. The Oslobreen Series, Upper Hecla Hoek of Ny Friesland, Spitsbergen. Geological Magazine 97: 447-460.

Halvorsen, E. 1989. A paleomagnetic pole position of Late Jurassic/Early Cretaceous dolerites from Hinlopenstretet, Svalbard, and its tectonic implications. Earth and Planetary Science Letters 94: 398-408.

Hansen, J., and L.E. Holmer. 2010. Diversity fluctuations and biogeography of the Ordovician brachiopod fauna in Northeastern Spitsbergen. Bulletin of Geoscience 85: 497-504.

Hansen, J., and L.E. Homer. 2011. Taxonomy and biostratigraphy of Ordovician brachiopods from northeastern Ny Friesland, Spitsbergen. Zootaxa 3076: 1-122. 
Harland, T.L., R.H. Wallis, and R.A. Gayer. 1966. A revision of the Lower Hecla Hoek succession in central north Spitsbergen and correlation elsewhere. Geological Magazine 103: 70-97.

Harland, W.B. 1997. Chapter 7 Northeastern Spitsbergen. Geological Society, London, Memoirs 17: 110-131.

Knight, I., K. Azmy, M.G. Greene, and D. Lavoie. 2007. Lithostratigraphic setting of diagenetic, isotopic, and geochemistry studies of Ibexian and Whiterockian carbonate rocks of the St. George and Table Head groups, western Newfoundland. Current Research, Newfoundland and Labrador Department of Natural Resources Geological Survey Report 07-1: 55-84.

Kosteva, N.N., and A.M. Teben'kov. 2006. Litologicheskaya kharakteristika kembrijskoordoviksikh otloshenij zapadnogo pobereshya proliva khinlopen, arkhipelag spitsbergen. Complex investigations of Spitsbergen Nature 6: 109-119.

Landing, E., J.A. Adrain, S.R. Westrop, and B. Kröger. 2011. Tribes Hill-Rochdale formations in east Laurentia: proxies for Early Ordovician (Tremadocian) eustasy on a tropical passive margin (New York and west Vermont). Geological Magazine 149: 93123.

Lavoie, D., A. Desrochers, G. Dix, I. Knight, and O. Salad Hersi. 2012. The great American carbonate bank in Eastern Canada: An Overview. In Derby, J.R., R.D. Fritz, S.A. Longacre, W.A. Morgan, and C.A. Sternbach, (editors), The Great American Carbonate Bank: The geology and economic reseources of the Cambrian-Ordovician Sauk megasequence of Laurentia: 499-523. American Association of Petroleum Geologists Memoir 98. 
Lehnert, O., S. Stouge, and P.A. Brandl. 2013. Conodont biostratigraphy in the Early to Middle Ordovician strata of the Oslobreen Group in Ny Friesland, Svalbard. Zeitschrift der Deutschen Gesellschaft für Geowissenschaften 164: 149-172.

Maletz, J., and D.L. Bruton. 2008. The Middle Ordovician Provenocitum procerulum radiolarian assemblage of Spitsbergen and its biostratigraphic correlation. Palaeontology 51: 1181-1200.

Morgan, W.A. 2012. Sequence stratigraphy of the Great American Carbonate Bank. In Derby, J.R., R.D. Fritz, S.A. Longacre, W.A. Morgan, and C.A. Sternbach, (editors), The Great American Carbonate Bank: The geology and economic resources of the CambrianOrdovician Sauk megasequence of Laurentia: 37-79. American Association of Petroleum Geologists Memoir 98.

Morris, N.J., and R.A. Fortey. 1976. Tironucola gen. nov. and its significance in bivalve evolution. Journal of Paleontology 50: 701-709.

Pope, M.C., and J.B. Steffen. 2003. Widespread, prolonged late Middle to Late Ordovician upwelling in North America: A proxy record of glaciation? Geology 31: 63-66.

Pope, M., and J.F. Read. 1998. Ordovician metre-scale cycles: implications for climate and eustatic fluctuations in the central Appalachians during a global greenhouse, non-glacial to glacial transition. Palaeogeography, Palaeoclimatology, Palaeoecology 138: 27-42.

Pratt, B.R., James, N. P. 1986. The St. George Group (Lower Ordovician) of western Newfoundland: tidal flat island model for carbonate sedimentation in shallow epeiric seas. Sedimentology 33: 313-343.

Ross, R.J.J., L.F. Hintze, R.L. Ethington, J.F. Miller, M.E. Taylor, and J.E. Repetski. 1997. The Ibexian, Lowermost Series in the North American Ordovician. U.S. Geological Survey Professional Paper 1579-A: 1-49. 
753 Smith, M.P., and J.A. Rasmussen. 2008. Cambrian-Silurian development of the Laurentian 754 margin of the Iapetus Ocean in Greenland and related areas. Geological Society of $755 \quad$ America Memoirs 202: 137-167.

756 Stouge, S., Christiansen, J.L., and Holmer, L.E. 2011. Lower Palaeozoic stratigraphy of 757 Murchinsonfjorden and Sparreneset, Nordauslandet, Svalbard. Geografiska Annaler, 758 Series A, Physical Geography 93: 209-226.

759 Taylor, J.F., J.E. Repetski, and R.C. Orndorff. 1992. The Stonehenge transgression: A rapid 760 submergence of the central Appalachian platform in the Early Ordovician. In Webby, 761 B.D., and J.R. Laurie, (editors), Global perspectives on Ordovician geology: 409-418. $762 \quad$ Balkema.

763 Vallance, G., and R.A. Fortey. 1968. Ordovician succession in North Spitsbergen.

764 Proceedings of the Geological Society of London 1648: 91-97.

765 Williams, M., and D.J. Siveter. 2008. The earliest leperdicope arthropod: A new genus from 766 the Ordovician of Spitsbergen. Journal of Micropalaeontology 27: 97-101. 


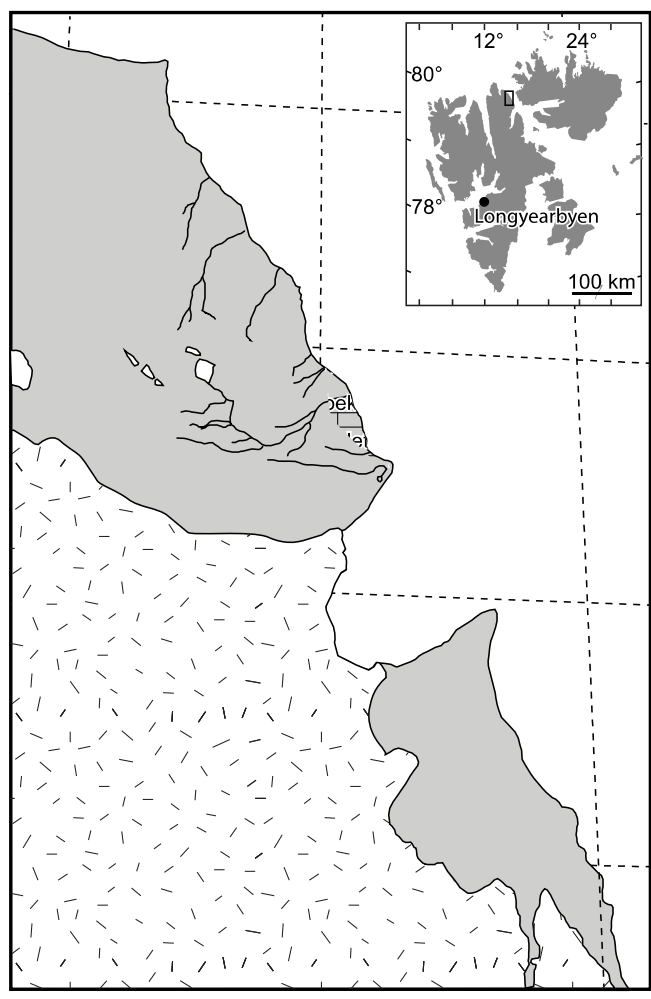

771

Figure 1. Map of the outcrop area adjacent to Hinlopenstretet, Ny Friesland, Spitsbergen

772 (Basissletta area in the north and the Olenidsletta in the south). Measured sections in circles:

773 FP, F-Promontory section; PO, Profilstranda-Olenidsletta Member section; PR, Profilbekken

774 River section; PS, Profilstranda section; SR, Spora River section.

775 


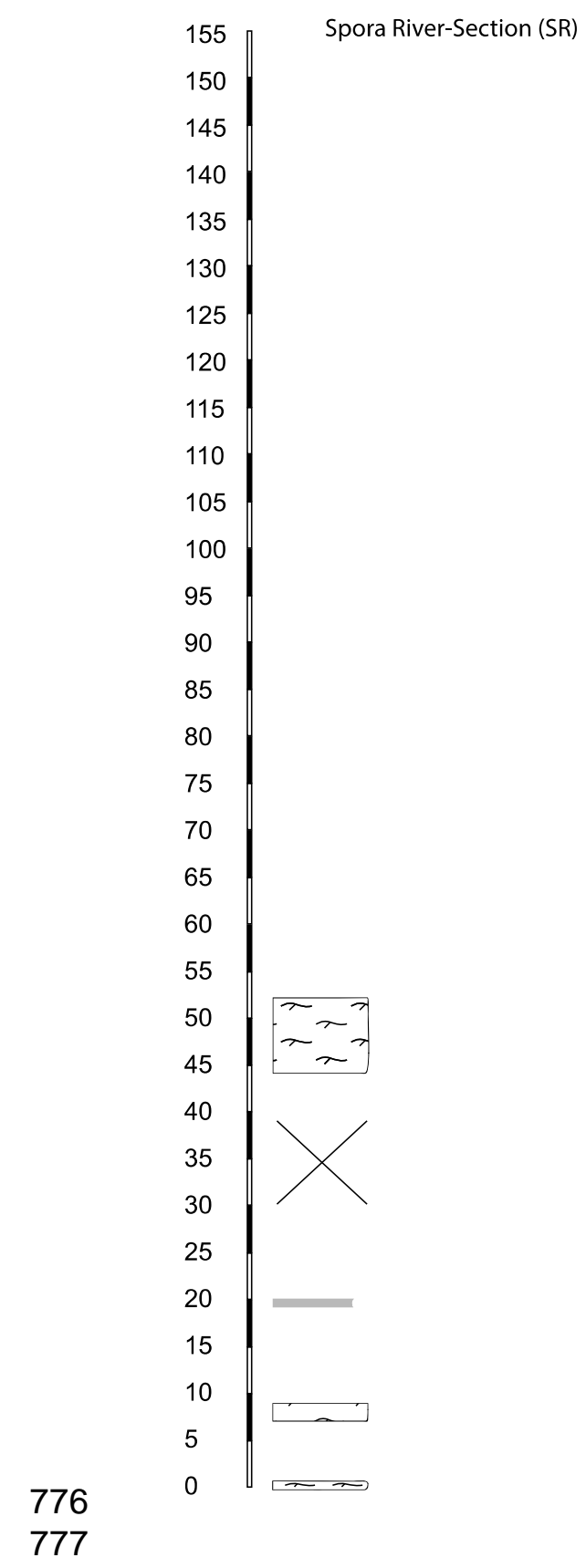

Figure 2. Spora River (SR) section. Abbreviations: Fm, Formation; Mbr, Member.

779 Explanation of symbols: 1, wavy bedded dolostone; 2, planar bedded limestone; 3, wavy 780 bedded dolostone, burrow churned dolostone, ribbon dolostone; 4, laminated, planar bedded 781 dolostone; 5, wavy narrowly bedded limestone; 6, laminated, planar bedded limestone; 7, 782 argillaceous-shaly; 8 , silty; 9, glauconitic; 10, thrombolitic, fenestral; 11, stromatolites; 12 , oolites; 13, flint nodules; 14 , flat pebble conglomerate; 15 , general intraclastic conglomerate; 16, dispersed silica; 17, erosional surface; 18, hardground; 19, not exposed; 20, trilobites; 21, 
785 gastropods; 22, cephalopods; 23, sponges; 24, echinoderms; 25, articulate brachiopods; 26, 786 inarticulate brachiopods.

787 

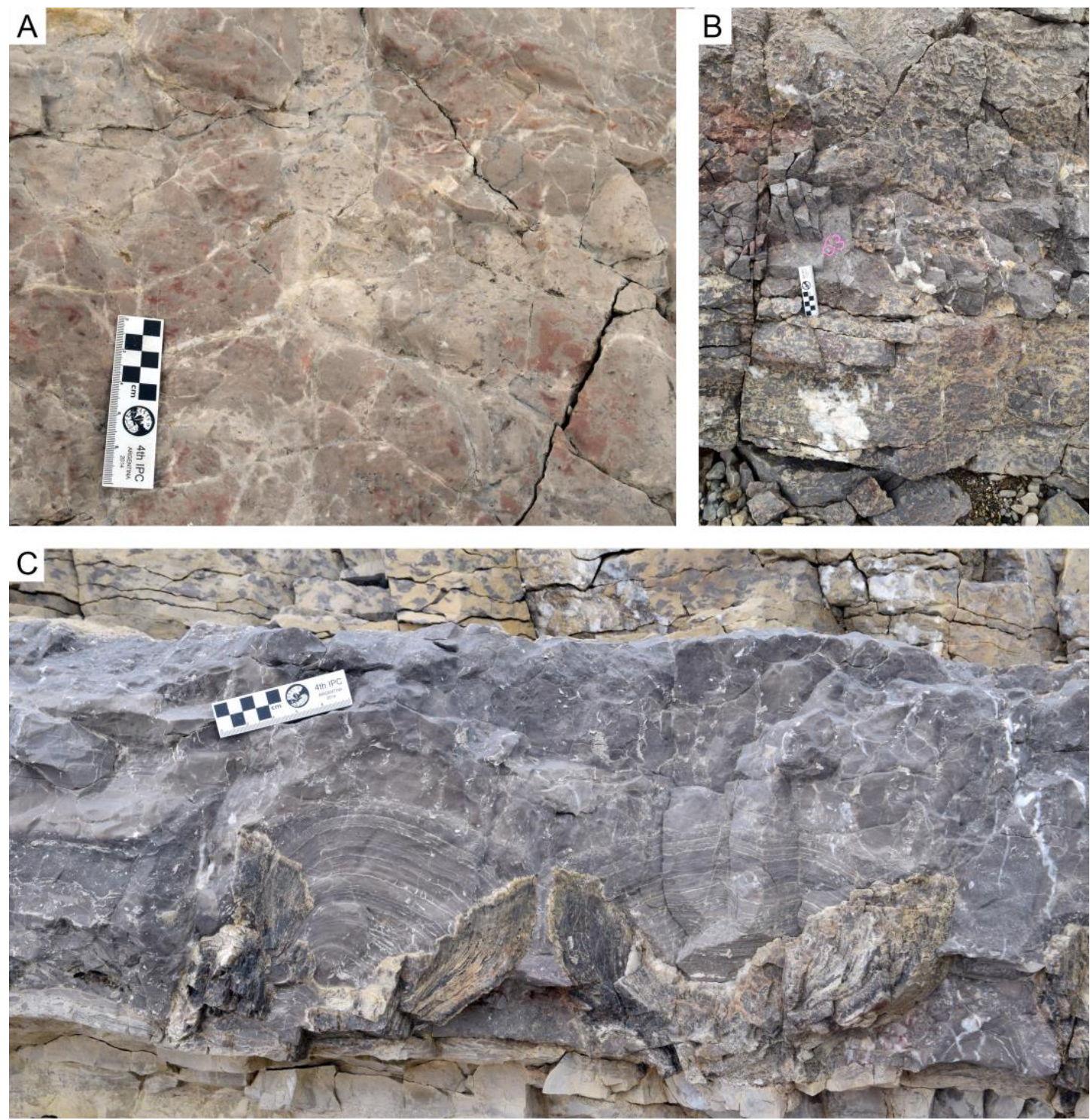

Figure 3. Field photographs of details of the Tokammane and Kirtonryggen formations,

791 Furongian?, Cambrian - Tremadocian, Ordovician, Spora River (SR) section, Ny Friesland,

792 Spitsbergen. A, pinkish thrombolitic - fenestral dolostone of the uppermost Tokammane

793 Formation, at SR section c. $40 \mathrm{~m}$; B, burrow-mottled dolostone of the uppermost Spora

794 Member, at SR section $63 \mathrm{~m}$; C, partly silicified domal stromatolite with underlying flat 795 pebble conglomerate, at SR section $148 \mathrm{~m}$. 

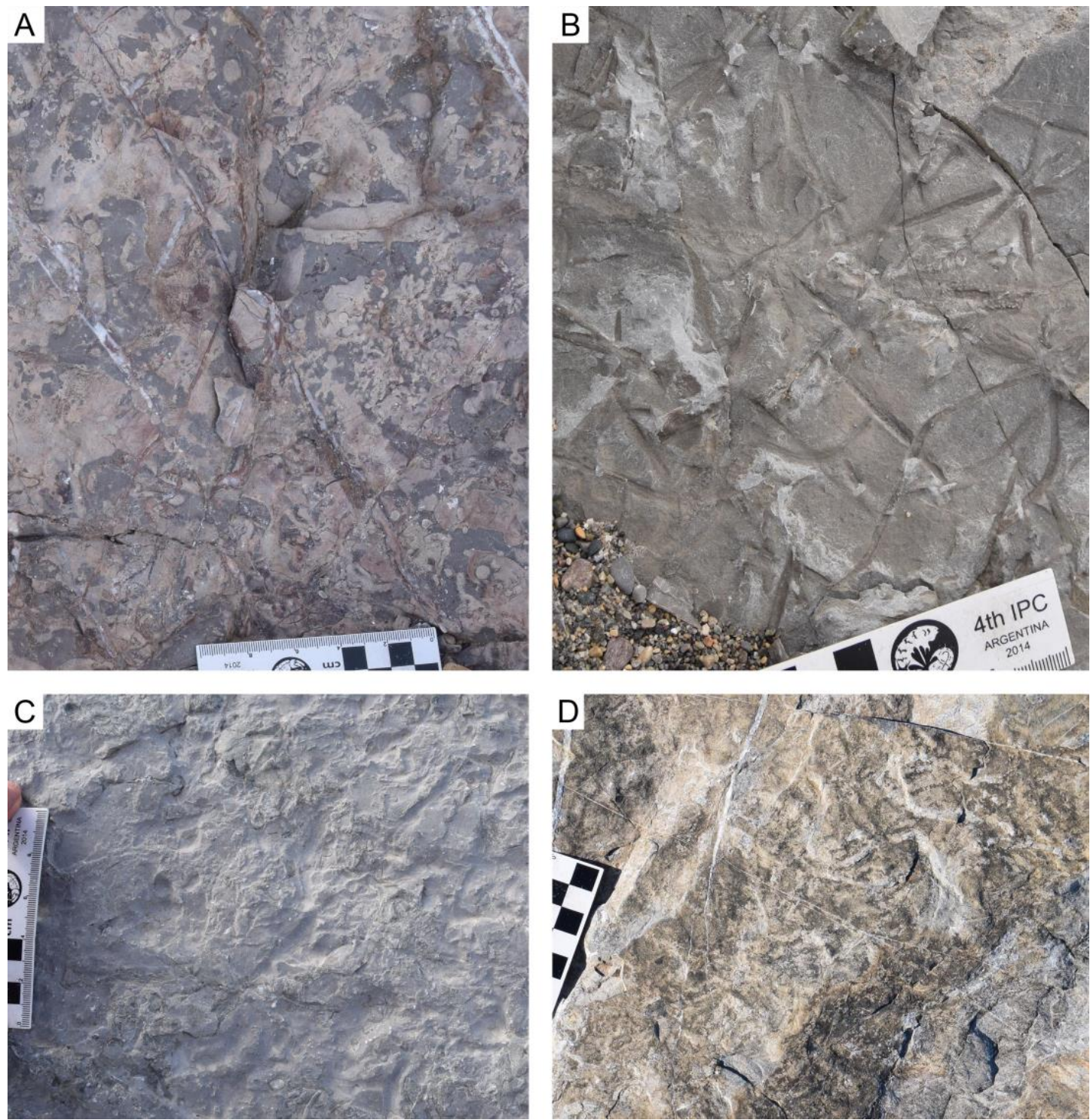

Figure 4. Field photographs of bedding surfaces with trace fossils in originally soft

sediments of the Kirtonryggen and Valhallfonna formations, Tremadocian-Darriwilian,

801 Ordovician, adjacent to Hinlopenstretet, Ny Friesland, Spitsbergen. A, Upper Spora Member, 

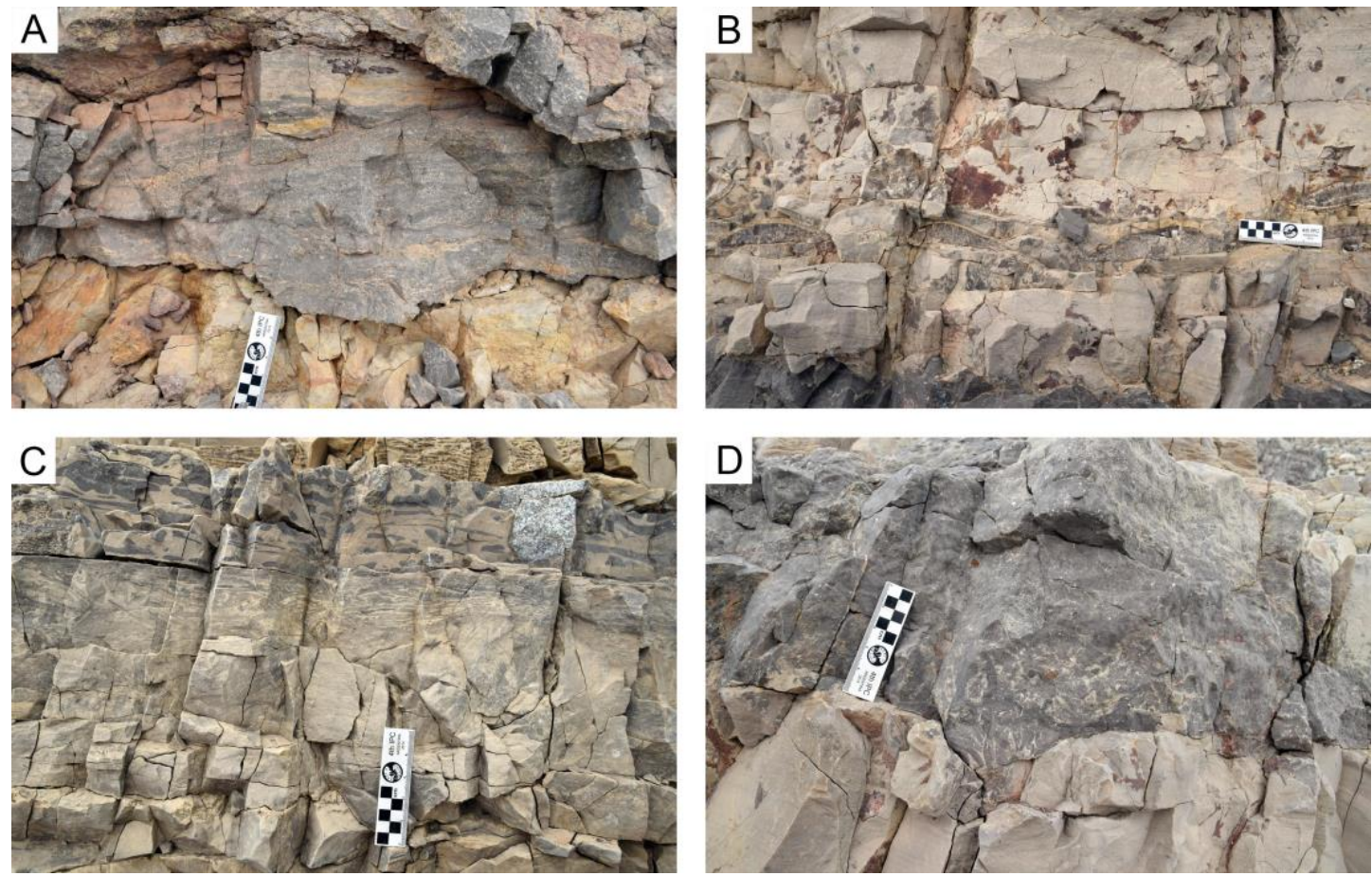

Figure 5. Field photographs of intraclastic horizons of the middle Basissletta Member,

809 Kirtonryggen Formation, Tremadocian, Ordovician, Spora River (SR) section, Ny Friesland,

810 Spitsbergen. A, intraclastic conglomerate over erosional surface, at SR section $142 \mathrm{~m}$; B,

811 oolitic ripple horizon within laminated dolo-mudstone at SR section $143 \mathrm{~m}$; C, flat pebble

812 conglomerate, at SR section $147 \mathrm{~m}$; D, flat pebble conglomerate with gutter cast and

813 vertically oriented clasts, at SR section $150 \mathrm{~m}$. 

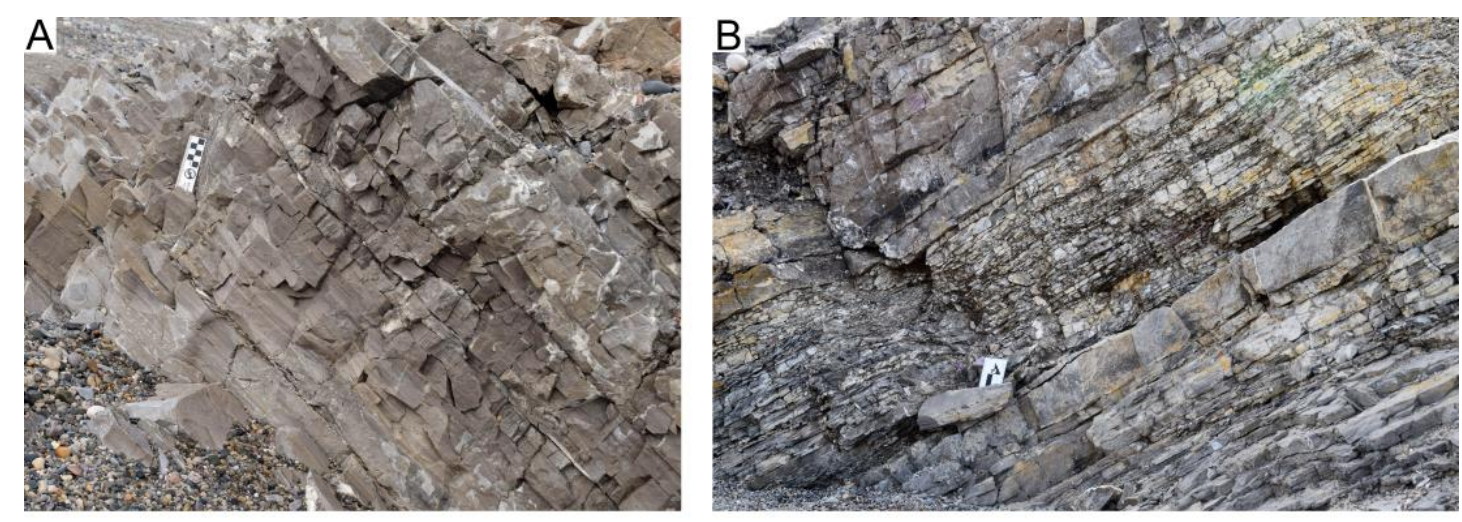

815
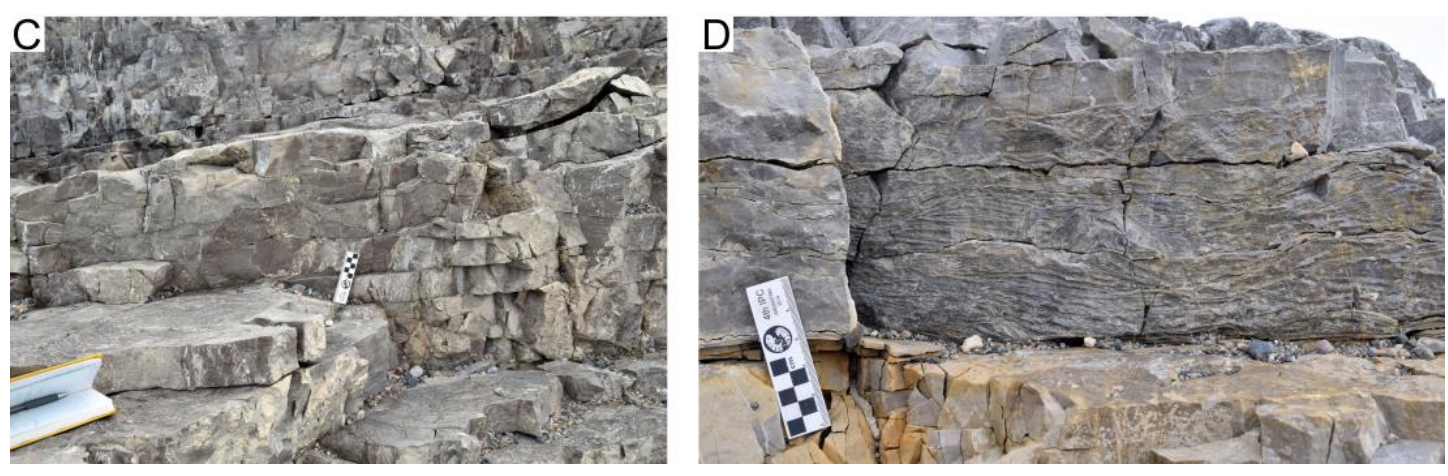

816

817 Figure 6. Field photographs of bedding features of the Basissletta Member, Kirtonryggen

818 Formation, Tremadocian, Ordovician, Ny Friesland, Spitsbergen. A, laminated dolo-

819 mudstone, at Profilstranda (PS) section $5 \mathrm{~m}$; B, argillaceous interval above flat pebble

820 conglomerate bed, at PS section 87-88 m; C, teepee structures in laminated dolo-mudstone, at

821 PS section $50 \mathrm{~m}$; D, hummocky cross stratification, at PS section $4 \mathrm{~m}$. 
Profilstranda - Section (PS)

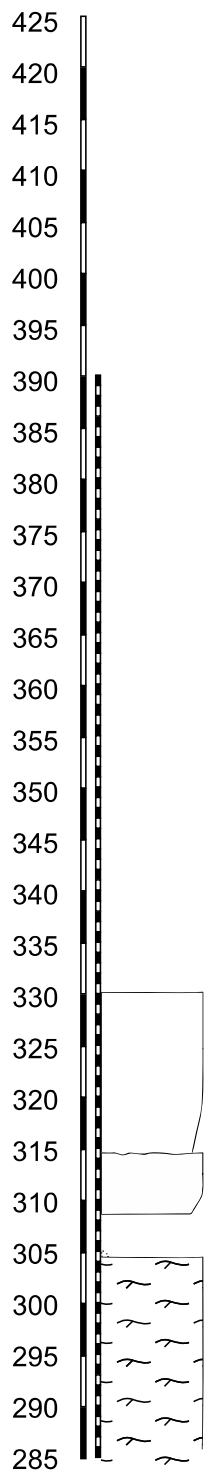

824

825 Figure 7. Profilstranda (PS) section, Basissletta and Nordporten members, Kirtonryggen

826 Formation, Tremadocian-Floian, Ordovician, adjacent to Hinlopenstretet, Ny Friesland,

827 Spitsbergen. For explanation of symbols see Figure 2.

828

829 

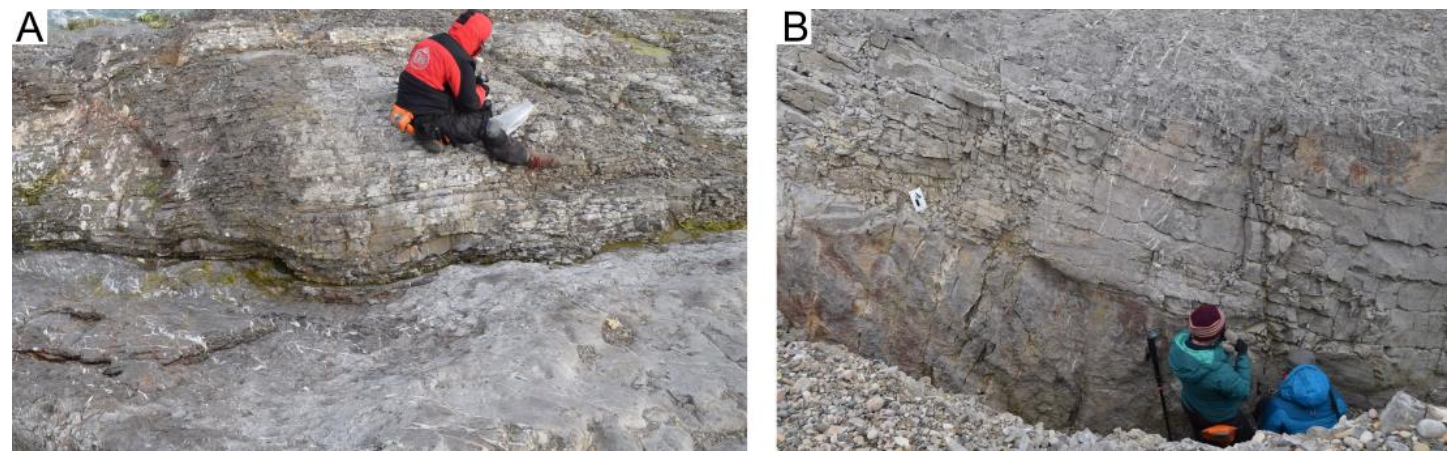

831 Figure 8. Field photographs of discontinuity surfaces within the Nordporten Member,

832 Kirtonryggen Formation, Floian, Ordovician, adjacent to Hinlopenstretet, Ny Friesland,

833 Spitsbergen. A, at Profilstranda (PS) section 219 m; B, at PS section $277 \mathrm{~m}$.

834 


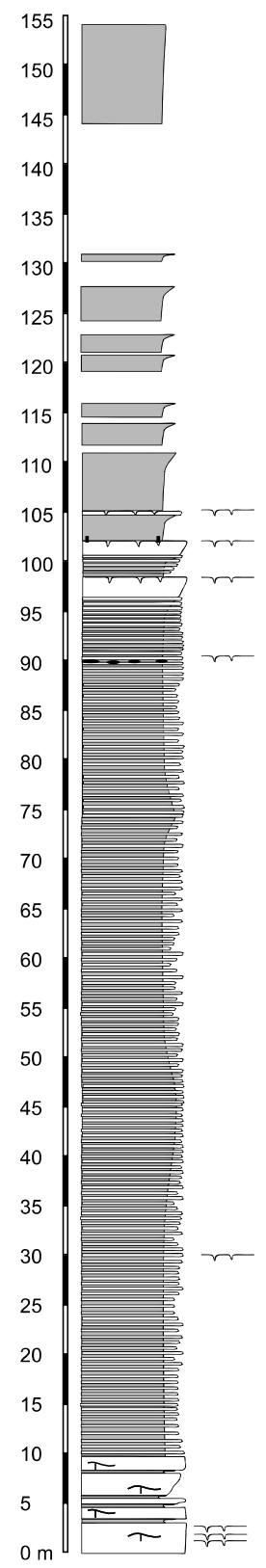

836

837 Figure 9. Profilstranda - Olenidsletta Member (PO) section, Olenidsletta Member,

838 Valhallfonna Formation, Floian-Dapingian, Ordovician, adjacent to Hinlopenstretet, Ny

839 Friesland, Spitsbergen. For explanation of symbols see Fig. 2. 

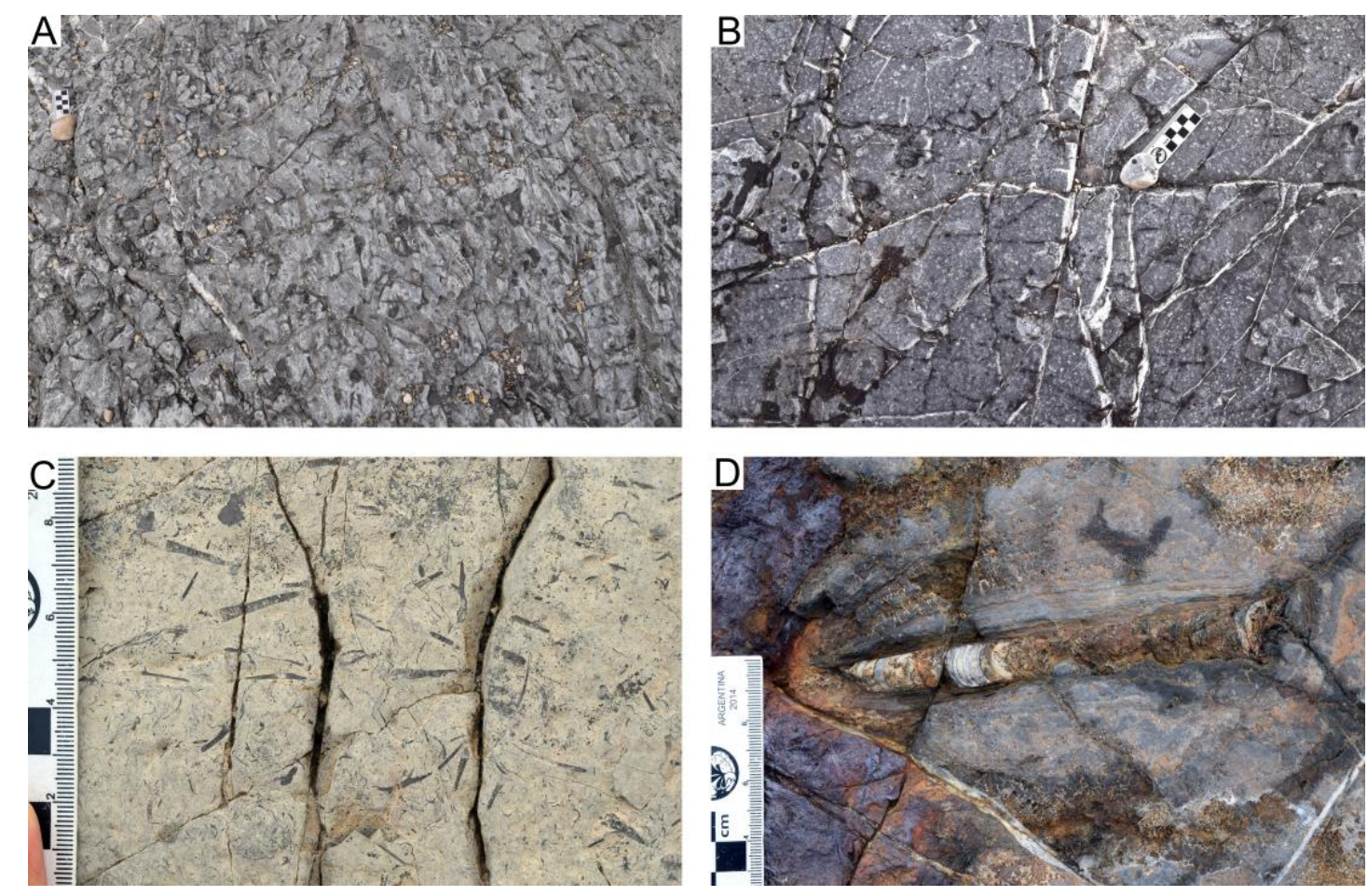

842 Figure 10. Field photographs of bedding surfaces of the Valhallfonna Formation, Floian-

843 Darriwilian, Ordovician, Basissletta area, adjacent to Hinlopenstretet, Ny Friesland,

844 Spitsbergen. A, surface with masses of fragments of orthoconic cephalopods, current aligned,

845 upper Olenidsletta Member, Profilbekken River (PR) section, bed correlates with bed at 128

$846 \mathrm{~m}$ at Profilstranda - Olenidsletta Member (PO) section; B, flat hardground with small borings

847 and ophiletid gastropod, Olenidsletta Member, at PO section $90 \mathrm{~m}$; C, bedding surfaces with

848 masses of minute orthoconic cephalopods and trilobite hash, uppermost Olenidsletta Member,

849 PR section; D, endocerid cephalopod with microbial overgrowth on iron (limonitic) stained

850 hardground in Profilbekken Member, at PR section $0 \mathrm{~m}$. 
853 Figure 11. F-promontory (FP) section, Profilbekken Member, Valhallfonna Formation, 854 Dapingian-Darriwilian, Ordovician, adjacent to Hinlopenstretet, Ny Friesland, Spitsbergen. 855 Note that the thickness measure in meters counts downward. For explanation of symbols see 856 Figure 2. 


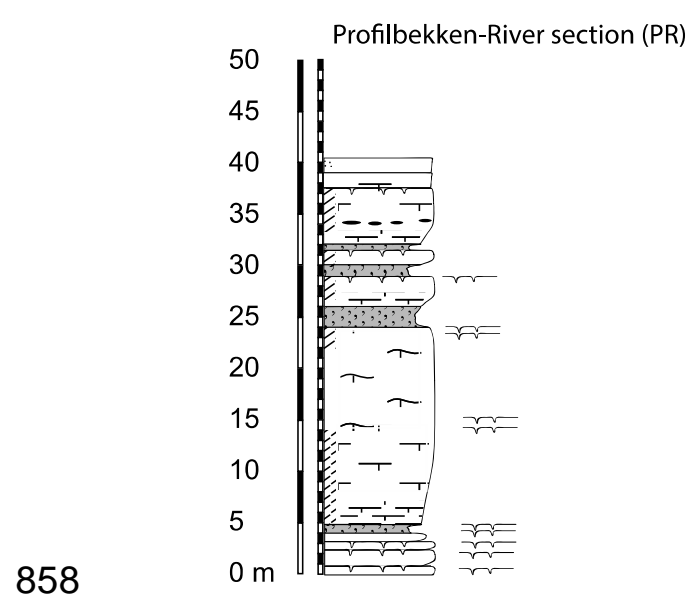

859 Figure 12. Profilbekken River (PR) section, Profilbekken Member, Valhallfonna

860 Formation, Dapingian-Darriwilian, Ordovician, adjacent to Hinlopenstretet, Ny Friesland,

861 Spitsbergen. For explanation of symbols see Figure 2.

862 

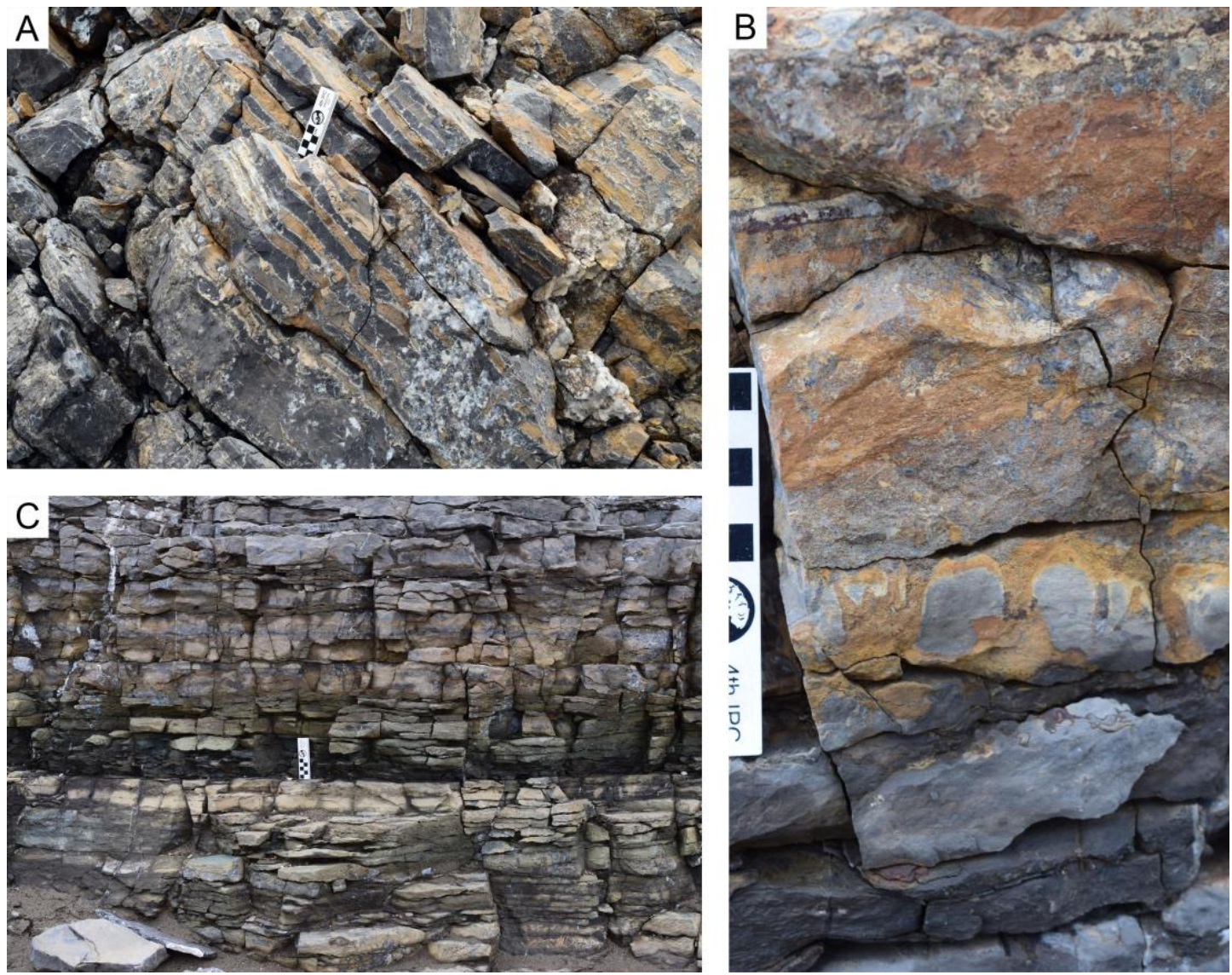

864

865 Figure 13. Field photographs of features of the Profilbekken Member, Valhallfonna

866 Formation, Dapingian-Darriwilian, Ordovician, adjacent to Hinlopenstretet, Ny Friesland,

867 Spitsbergen. A, typical banded, silicified, lime-mudstone of the Profilbekken Member, at PR

868 section c. $10 \mathrm{~m}$; B, iron (limonitic) stained hardground with prominent vertical borings, at PR

869 section $0 \mathrm{~m}$; C, upper glauconite bed, at PR section $32 \mathrm{~m}$. 

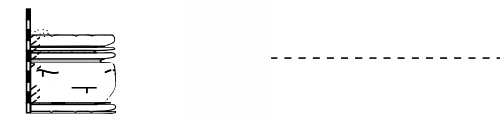

$\longrightarrow$
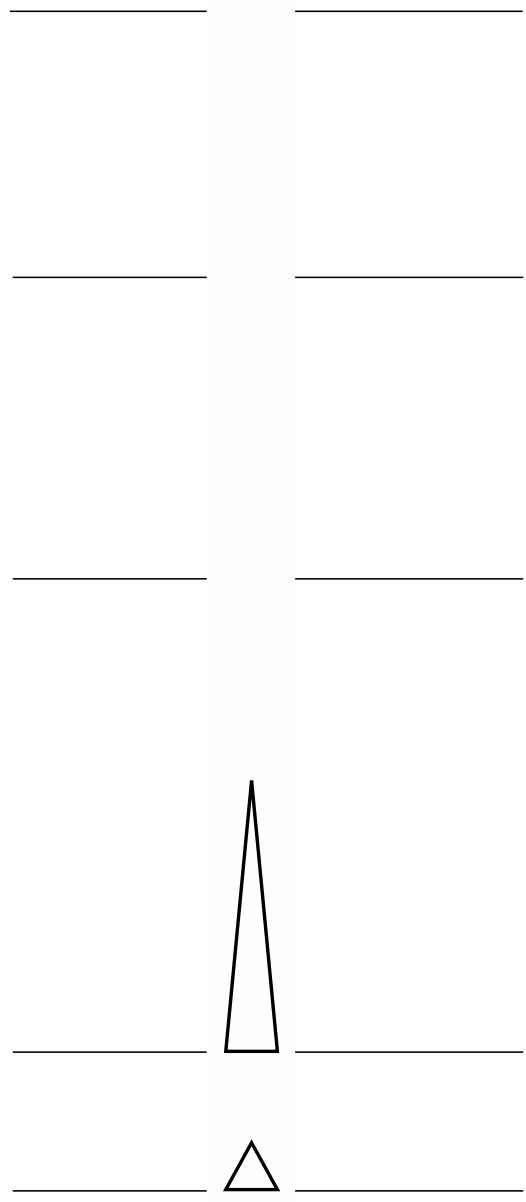

873 Figure 14. Stratigraphic scheme of the Ordovician adjacent to Hinlopenstretet, Ny

874 Friesland, Spitsbergen.1, Fortey (1980), Fortey and Bruton (2013); 2, Lehnert et al. (2013); 3,

875 Cooper and Fortey (1982). 


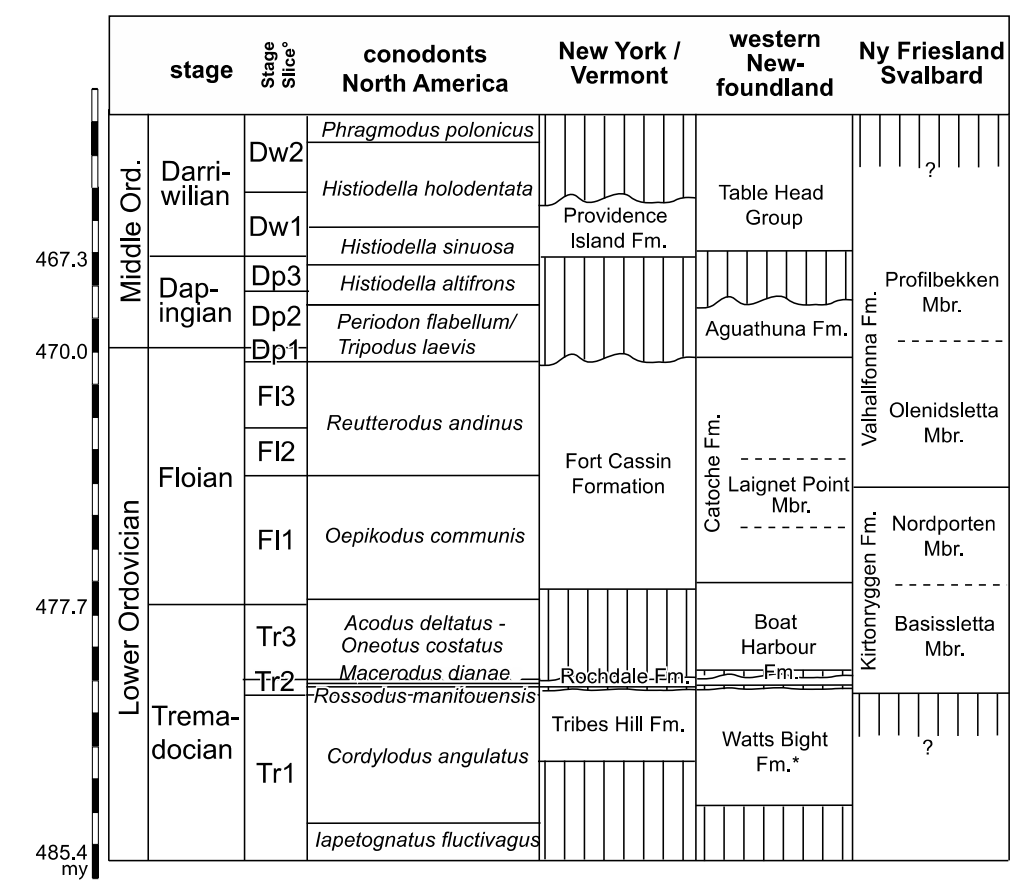

876

877

878 Figure 15. Correlation of of the Ordovician adjacent to Hinlopenstretet, Ny Friesland,

879 Spitsbergen with selected successions of eastern Laurentia (eastern US and Canada). Based

880 on Cooper et al. (2012); Kröger and Landing (2011), Lavoie et al. (2012), ${ }^{\circ}$ stage slices of

881 Bergström et al. (2009), * range according to Boyce et al. (2011).

882

883

884 